\title{
Lipotoxic Impairment of Mitochondrial Function in $\beta$-Cells: A Review
}

\author{
Axel Römer (D), Thomas Linn and Sebastian F. Petry *(D)
}

check for updates

Citation: Römer, A.; Linn, T.; Petry, S.F. Lipotoxic Impairment of Mitochondrial Function in $\beta$-Cells: A Review. Antioxidants 2021, 10, 293. https://doi.org/10.3390/ antiox10020293

Academic Editors: Volker Böhm and Gunter Peter Eckert

Received: 28 November 2020

Accepted: 11 February 2021

Published: 15 February 2021

Publisher's Note: MDPI stays neutral with regard to jurisdictional claims in published maps and institutional affiliations.

Copyright: (c) 2021 by the authors. Licensee MDPI, Basel, Switzerland. This article is an open access article distributed under the terms and conditions of the Creative Commons Attribution (CC BY) license (https:// creativecommons.org/licenses/by/ $4.0 /)$.
Clinical Research Unit, Center of Internal Medicine, Justus Liebig University, 35392 Giessen, Germany; Axel.Roemer@ernaehrung.uni-giessen.de (A.R.); Thomas.Linn@innere.med.uni-giessen.de (T.L.)

* Correspondence: sebastian.petry@innere.med.uni-giessen.de; Tel.: +49-641-985-42841; Fax: +49-641-985-42849

\begin{abstract}
Lipotoxicity is a major contributor to type 2 diabetes mainly promoting mitochondrial dysfunction. Lipotoxic stress is mediated by elevated levels of free fatty acids through various mechanisms and pathways. Impaired peroxisome proliferator-activated receptor (PPAR) signaling, enhanced oxidative stress levels, and uncoupling of the respiratory chain result in ATP deficiency, while $\beta$-cell viability can be severely impaired by lipotoxic modulation of PI3K/Akt and mitogenactivated protein kinase (MAPK)/extracellular-signal-regulated kinase (ERK) pathways. However, fatty acids are physiologically required for an unimpaired $\beta$-cell function. Thus, preparation, concentration, and treatment duration determine whether the outcome is beneficial or detrimental when fatty acids are employed in experimental setups. Further, ageing is a crucial contributor to $\beta$-cell decay. Cellular senescence is connected to loss of function in $\beta$-cells and can further be promoted by lipotoxicity. The potential benefit of nutrients has been broadly investigated, and particularly polyphenols were shown to be protective against both lipotoxicity and cellular senescence, maintaining the physiology of $\beta$-cells. Positive effects on blood glucose regulation, mitigation of oxidative stress by radical scavenging properties or regulation of antioxidative enzymes, and modulation of apoptotic factors were reported. This review summarizes the significance of lipotoxicity and cellular senescence for mitochondrial dysfunction in the pancreatic $\beta$-cell and outlines potential beneficial effects of plant-based nutrients by the example of polyphenols.
\end{abstract}

Keywords: lipotoxicity; free fatty acids; oxidative stress; mitochondrial dysfunction; beta cell; diabetes mellitus; polyphenol; ageing

\section{Introduction}

The onset and progression of diabetes mellitus (DM) is crucially determined by the deterioration of the glucose-stimulated insulin secretion (GSIS) of pancreatic $\beta$-cells. In 2019, there were more than 460 million patients with DM worldwide with a steadily rising prevalence $(9.3 \%)$ over the last few decades [1]. The impaired action of insulin in these patients leads to elevated plasma glucose levels. Chronic hyperglycemia can damage various molecules and tissues by glycation [2]. To prevent these complications, the supply with an adequate amount of insulin is necessary. As insulin secretion demands a lot of biochemical energy [3] and mitochondria contribute to $98 \%$ of cellular adenosine triphosphate (ATP) [4], their proper function becomes a major aspect in developing $\beta$-cell dysfunction and decay.

The progression of type 2 diabetes mellitus (T2DM) is accompanied by elevated free fatty acids (FFAs) [5-7] as well as the deterioration of the lipid metabolism. FFA are known to impair the function of $\beta$-cells and promote their failure by various mechanisms [8], among others, by toxic metabolites of lipid degradation, the activation or dysregulation of signaling pathways, oxidative stress, and an altered energy production. By mediating this so-called lipotoxicity, FFA can impair the mitochondrial metabolism and other compartments of the $\beta$-cell and disturb its capacity of both insulin synthesis and release. FFAs increase insulin resistance by several signaling pathways, including altered translocation 
of glucose transporter (GLUT). FFAs are therefore one of the major promotors of developing T2DM [9]. Nevertheless, FFAs are physiologically required for energy demands, as components of membranes or signaling molecules, and there is no defined qualitative or quantitative cut-off at which toxic effects commence. In general, lipotoxicity is defined as the impairment of cellular functions like mitochondrial respiration, protein translation and function, and induction of cell death mediated by the accumulation of FFAs. However, the underlying mechanisms are more complex and involve an imbalance between uptake, storage, and utilization of FFAs.

Beside elevation of FFA blood and tissue levels, and associated disorders of lipid metabolism, cellular senescence [10] is the second major contributor to the increasing prevalence of T2DM [11]. The rate of apoptotic events is increased while proliferation is disfavored with age, leading to an incremented decay of the endocrine pancreas. Increased levels of reactive oxygen species (ROS) and DNA damage diminish the regenerative capacity and function of $\beta$-cells correlating with a general impairment of insulin production and secretion machinery as well as an increased rate of apoptosis. There is also a connection between enhanced cellular stress leading to an age-dependent impairment of the lipid metabolism marked by increased plasma triglyceride (TG) levels and reduced postprandial TG clearance rates [12]. Likewise, there is a correlation between increased plasma FFA and age [13]. Concomitant with a decreased antioxidative capacity of $\beta$-cells [14], which is yet challenged by both FFA and age [15], this would promote lipotoxic effects ultimately leading to an acceleration of senescence and dysfunction of $\beta$-cells.

There are available data which point towards beneficial effects of plant-based nutrients [16]. Their beneficial effects are mainly, but not completely, thought to be mediated by their phytochemicals, consisting of heterogeneous substances with a variety of different bioactive molecules [17]. Beside e.g., carotenoids, glucosinolates, lectins, terpenes, alkaloids, and polysaccharides [18,19], the vast group of polyphenols has been investigated extensively for positive effects to improve insulin resistance and blood glucose levels [20]. Polyphenols can contain molecules like tannins, flavonoids, anthocyanins, proanthocyanidins, or derivatives of different organic acids [21-23], which are able to enhance action of insulin [24], glucose transport [25], or decrease intestinal carbohydrate hydrolysis [26-28]. These compounds can modulate antioxidative enzymes or cellular stress responses by gene expression [29-31] or regulation of cytokines and signaling pathways to improve $\beta$-cell function. By scavenging radicals and inducing the upregulation of antioxidative enzymes, phytochemicals can mitigate oxidative stress [32]. They directly control single steps in the lipid metabolism like uptake and storage of FFA to abate their toxic intermediates [33]. Moreover, phytochemicals can directly reverse the lipotoxic effects of FFAs by counteracting their adverse regulatory effects, e.g., by downregulating the respective signal pathways of insulin secretion or apoptosis [34]. There is a growing body of evidence that polyphenols could be able to reverse the negative effects of lipotoxicity and preserve, restore, and promote the physiological functions of $\beta$-cells.

The aim of this review is to (I) summarize the knowledge of basic research on lipotoxicity directed against $\beta$-cells, in particular their mitochondria, with special regard to methodology, (II) elucidate the connection with cellular senescence, and (III) outline potential beneficial effects of dietary measures employing polyphenols as an example.

\section{Literature Search}

The literature search based for this review was executed on 7th of September and 31st of December 2020 on PubMed. The search term (lipotox * OR "free fatty acid *") AND (mitochondria * OR polyphenol * OR flavonoid * OR ageing) AND "beta cell * yielded a total of 149 primary articles. The publication dates ranged from February 1977 to September 2020. After screening literature, 22 articles were excluded. Exclusion criteria were no suitable topic (11 exclusions), not written in English (five exclusions), reviews with no primary data (five exclusions) and no available full-texts (one exclusion), leaving 127 articles. Three 
reviews with primary data have been included. A flow chart of the literature search is given in Figure 1. A list of all screened articles is provided in Supplementary Material.

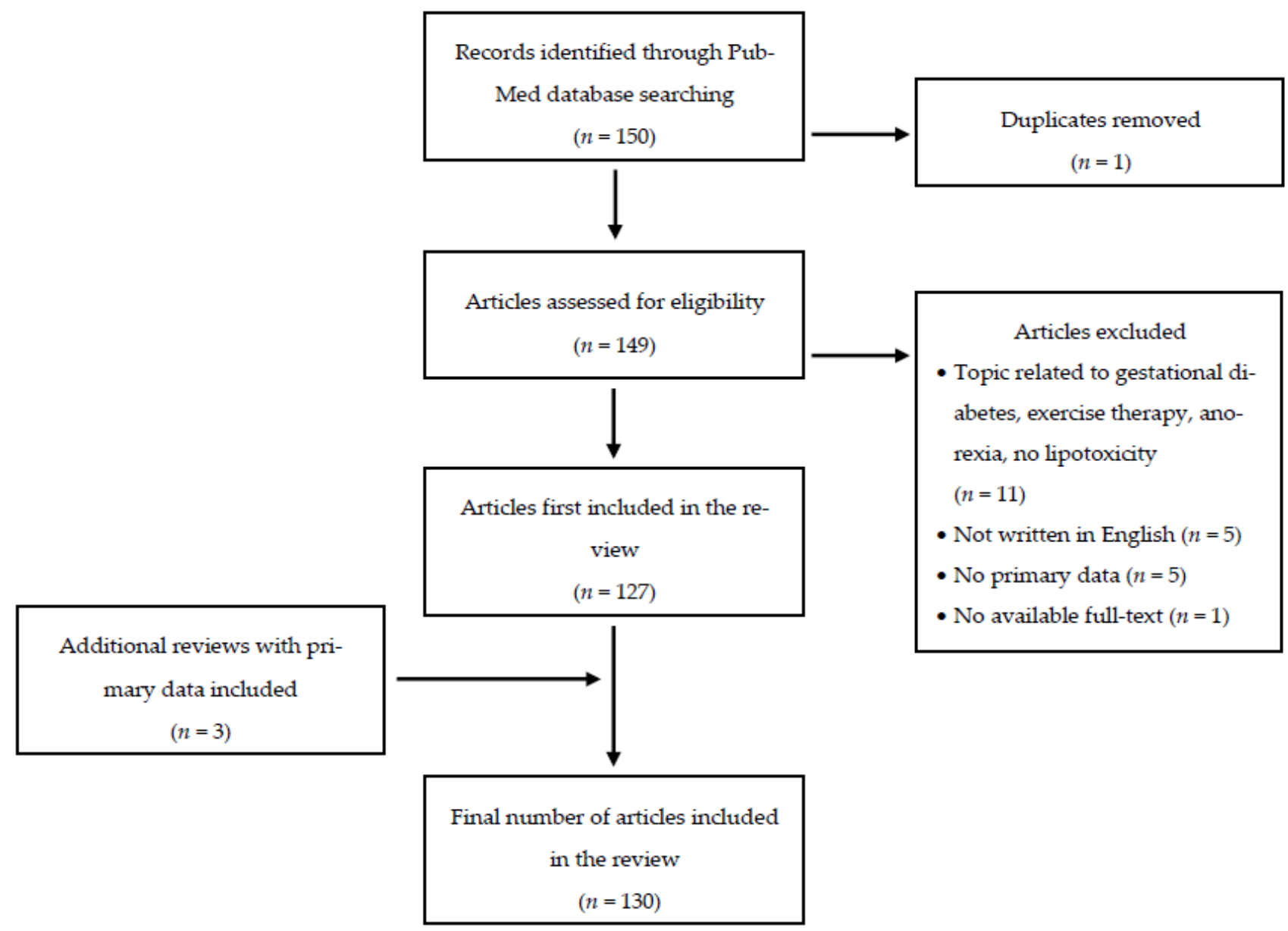

Figure 1. Flow diagram of the literature search on PubMed, www.ncbi.nlm.nih.gov/pubmed.

\section{Factors Influencing Lipotoxic Outcomes in Tissue Culture}

Since lipotoxicity cannot merely be defined by exceeding a specified concentration of FFA, the respective experimental setup must be considered closely when assessing experimental outcomes.

The employed amount of FFA is one of the key factors for activating lipotoxic pathways. However, only few authors state the rationale for the chosen concentrations. A point of reference could be the serum FFA level of healthy and diabetic subjects and animals.

Spectroscopic analysis of blood samples revealed that the total FFA concentration in diabetic human serum is ranging from 3.5 to $15 \mathrm{mM}$, also giving concentrations of specific FFA like oleic acid (OA) with 0.74-3.9 mM and palmitic acid (PA) with 1.0-3.8 mM [35-38]. These data also reveal an increase of OA and PA concentrations in diabetic compared to healthy individuals of approximately $10 \%$ [36]. Serum concentrations of rodents are lower with a total FFA serum concentration of $0.8-1.5 \mathrm{mM}[39,40]$. Authors claim that a FFA concentration range of $0.5-2.0 \mathrm{mM}$ is suitable to mimic lipotoxicity in T2DM [41,42]. There is no detailed information about specific FFA concentrations for pancreatic tissue, which would indicate suitable concentrations for experimental models. Given the distinct magnitude of $\beta$-cell dysfunction on parameters like ATP production or insulin secretion, the increase of $10 \%$ in FFA concentration appears to be insignificant. These facts could indicate that considering the total FFA concentration is not a satisfactory parameter to determine a lipotoxic environment. A small increase of FFA concentrations could be sufficient to have greater impact on deteriorations of $\beta$-cell metabolism. All these facts 
are raising the issue which concentrations should be employed for inducing lipotoxicity in an experimental setup. The screening of the available literature revealed significant differences. Most commonly $500 \mu \mathrm{M}$ were used with a total range of $10-2000 \mu \mathrm{M}$. From the total of performed treatments with FFA $(n=104)$, there are available data for the following concentration ranges: $10-99 \mu \mathrm{M}(n=12), 100-499 \mu \mathrm{M}(n=53), 500 \mu \mathrm{M}(n=49)$, 501-2000 $\mu \mathrm{M}(n=18)$ (Table 1). Single $(n=82)$ as well as multiple concentrations $(n=22)$ have been employed.

Table 1. Frequency of FFA concentrations used in screened literature focused on lipotoxicity $(n=132)$. Free fatty acids (FFA).

\begin{tabular}{cc}
\hline Concentration of FFA & Frequency in Screened Articles \\
\hline $10-99 \mu \mathrm{M}$ & 12 \\
$100-499 \mu \mathrm{M}$ & 53 \\
$500 \mu \mathrm{M}$ & 49 \\
$501-2000 \mu \mathrm{M}$ & 18 \\
\hline
\end{tabular}

Insulin secretion and ATP levels were frequently examined. Treatment with 400 or $500 \mu \mathrm{M}$ FFA led to a $6-90 \%$ decrease in ATP [4,43-45]. An incremented concentration of $2000 \mu \mathrm{M}$ did not mediate higher toxicity [46]. A 15-70\% diminished insulin secretion was induced by a short-or medium-term treatment (up to $72 \mathrm{~h}$ ) with 400 or $500 \mu \mathrm{M}$ FFA [47,48]. Exposure to $100 \mu \mathrm{M}$ for several weeks led to a $20 \%$ decrease [49]. Glucose stimulation treatment was conducted with comparable concentrations of around $25 \mathrm{mM}$. The available data did neither reveal a dose dependent effect of FFA on insulin secretion, nor on ATP levels. Since the described protocols differed a lot in detail, e.g., regarding solvents, bovine serum albumin (BSA) amount, and incubation times, results were only comparable to a limited extent. For other readouts, the number of studies was too small to examine dose dependency.

In most tissue culture reports single rather than multiple FFA were examined. Hence, another key modulator for in vitro tissue culture is the selected type of FFA. It is noteworthy that only a small number of FFA have been used repeatedly for studying molecular pathways of cells. The most common design was the usage of single PA $(n=52)$, followed by the combination of PA + OA $(n=20)$, the combination of PA + OA + any additional FFA $(n=8)$, the combination of PA + any additional FFA $(n=6)$, treatment with single OA $(n=6)$, or with any single FFA $(n=4)$. Concentration range of combined FFA culture was 100-2000 $\mu \mathrm{M}$ (PA + OA), 200-1000 $\mu \mathrm{M}$ (PA + OA + any FFA) and 10-500 $\mu \mathrm{M}$ (PA + any FFA). The group of FFA used occasionally includes myristic, stearic, palmitoleic, linoleic, linolenic, methylpalmitic, docosahexaenoic, and arachidonic acid (Table 2). The combination of different types of FFA could be a suitable model for mimicking a physiological FFA composition [50]. 
Table 2. Frequency of FFA and FFA combinations used in screened literature $(n=96)$. Free fatty acids (FFA). Palmitic acid (PA). Oleic acid (OA). Any FFA is referring to myristic, stearic, palmitoleic, linoleic, linolenic, methylpalmitic, docosahexaenoic, and arachidonic acid.

\begin{tabular}{cc}
\hline FFA & Frequency in Screened Articles \\
\hline PA & 52 \\
PA and OA & 20 \\
PA and OA and any FFA & 8 \\
PA and any FFA & 6 \\
OA & 6 \\
Any FFA & 4 \\
\hline
\end{tabular}

Furthermore, the preparation of FFA solutions can have a major impact on the outcome depending on the applied assays. For dissolving FFA, the reviewed articles used ethanol $(n=25), \mathrm{NaOH}$ or $\mathrm{NaCl}(n=12)$, dimethyl sulfoxide $(n=4)$, and methanol $(n=3)$, while most articles did not specify how the FFA solutions have been prepared $(n=54)$ (Table 3). The use of solvents should be tested on key parameters like viability and also insulin concentration because they can affect the outcome by varying cytotoxic properties [51,52]. In addition, the total BSA concentration as well as the molar FFA:BSA ratio can have a drastic impact on the mediated lipotoxicity as well as specifically on the MTT viability assay [53,54], and were only described in detail in half of the studies $(n=53)$. The utilized BSA content in the respective cell culture media varied markedly, ranging between $0.05-5 \%$ for comparable FFA concentrations $[55,56]$. The molar FFA:BSA ratio determines the amount of unbound FFA in the treatment media, representing a more decisive parameter when compared to the total FFA concentration according to some authors [57]. Commonly used molar FFA:BSA ratios within the literature were at maximum 5:1. It was suggested to not exceed this ratio [57], whereas due to hyperlipidemia, higher ratios could be suitable for modeling the pathophysiological state in T2DM [58].

Table 3. Frequency of used solvents in screened literature $(n=98)$.

\begin{tabular}{cc}
\hline Solvent & Frequency in Screened Articles \\
\hline Ethanol & 25 \\
NaOH or NaCl & 12 \\
Dimethyl sulfoxide & 4 \\
Methanol & 3 \\
No further information & 54 \\
\hline
\end{tabular}

The vast amount of the reviewed data $(n=199)$ were obtained from rodent cell culture (rodent $n=96$, human $n=12$, monkey $n=1$ ) and animal models (Table 4). If comparing the results obtained from cell lines and primary $\beta$-cells, there are no remarkable differences if same FFA concentrations are applied $[59,60]$. There is no indication that there is an adaption of applied FFA concentrations depending on whether rodent cell lines and isolated human islets are used. This leads to the question if FFA concentrations used in rodents are suitable for studying human-based systems. 
Table 4. Frequency of cell culture models used in screened literature $(n=109)$. Insulinoma (INS-1). Mouse insulinoma 6 (MIN6). Human embryonic kidney 293 (HEK 293). Rat insulinoma (Rinm5f). Hamster islet transformed-tioguanine resistant clone 15 (HIT-T15). Hepatoblastoma (HepG2). Chinese hamster ovary (CHO). NOD/Lt (NIT1). $\beta$-tumour cell ( $\beta \mathrm{TC} 6)$. CV-1 in origin simain-1 (COS1).

\begin{tabular}{cc}
\hline Cell Line & Frequency in Screened Articles \\
\hline INS-1 (rodent) & 57 \\
MIN6 (rodent) & 23 \\
HEK 293 (human) & 7 \\
Rinm5f (rodent) & 5 \\
HIT-T15 (rodent) & 5 \\
HepG2 (human) & 3 \\
CHO (rodent) & 2 \\
EndoC-ßH1 (human) & 2 \\
NIT1 (rodent) & 2 \\
BTC6 (rodent) & 2 \\
BRIN-BD11 (rodent) & 2 \\
COS1 (monkey) & 1 \\
\hline
\end{tabular}

\section{Factors Influencing Lipotoxic Outcomes in Animal Models}

In animal experiments a high fat diet ranging from $20-60 \%$ fat content $(n=12)$ was reported. There was no direct treatment of animals with isolated FFA $(n=18)$.

Animal models $(n=73)$ included 23 studies using wild types $(\mathrm{C} 57 \mathrm{BL} / 6 n=15$, C57BL/6J $n=8$ ) and 11 using specific mutations of metabolism (C57BL/ 6 mutants $n=8$, C57BL/6J mutants $n=3)$, Wistar rats $(n=11)$, Sprague Dawley rats $(n=9), \mathrm{db} / \mathrm{db}(n=4)$, $\mathrm{ob} / \mathrm{ob}, \mathrm{CD} 1$ mice, Zucker diabetic fatty rats (each $n=3$ ) and ICR, NMRI, KK-Ay, Atg7f/f, HcB19 and nu/nu mice (each $n=1$ ) (Table 5). In 17 articles, isolated islets from humans were investigated. The mentioned parameters like chosen model, type, and concentration of FFA as well as preparation of FFA stock solutions must be carefully considered while comparing the different results.

Table 5. Frequency of animal models used in screened literature $(n=73)$. Institute for Cancer Research (ICR). Naval Medical Research Institute (NMRI). Diabetic KK and lethal yellow (Ay) mice (KK-Ay). Ubiquitin-like modifier-activating enzyme (ATG7). TXNIP deficiency (HcB19).

\begin{tabular}{cc}
\hline Animal Model & Frequency in Screened Articles \\
\hline wild type C57BL/6 and C57BL/6J mouse & 15 and 8 \\
mutant C57BL/6 and C57BL/6J mouse & 8 and 3 \\
Wistar rat & 11 \\
Sprague Dawley rat & 9 \\
db/db mouse & 4 \\
ob/ob mouse & 3 \\
CD1 mouse & 3 \\
Zucker diabetic fatty rat & 3 \\
ICR mouse & 1 \\
NMRI mouse & 1 \\
KK-Ay mouse & 1 \\
Atg7f/f mouse & 1 \\
HcB19 mouse & 1 \\
nu/nu mouse & 1 \\
\hline
\end{tabular}

\section{Lipotoxic Action of FFA on Mitochondria in $\beta$-Cells}

\subsection{Detrimental Effects of Elevated FFA in Type 1 and Type 2 Diabetes Mellitus}

FFA are well known to mediate toxic effects and impair the function of $\beta$-cells enhancing blood glucose levels and increasing the cellular abundance of glucose molecules. Since T2DM patients are exposed to elevated FFA blood levels, they are considered at special risk to suffer from lipotoxic effects including damaged $\beta$-cells. 
Both reduced insulin levels and action promote lipolysis, but the specific cause why FFA are elevated remain mostly unclear [61]. The abundance of energy generated by the so-called "obesogenic" environment, hallmarked by low physical activity and high caloric, Western-style diet rich in short-chain carbohydrates and animal fats [11], is considered an important link between elevated FFA in T2DM, obesity, and related deteriorations in lipid metabolism. Importantly, a pathological insulin resistance is promoted by lipotoxic effects [43], representing a major mechanism for obesity as a risk factor for T2DM. In type $1 \mathrm{DM}$, there is no predominant correlation between lipotoxicity and destruction of $\beta$-cells [62].

FFA are able to mediate lipotoxicity at different stages of their metabolism covering the range from uptake [63] to degradation [64]. Therefore, lipotoxicity is of a multifactorial etiology and not restricted to a single specific pathway. The following sections will elucidate the underlying pathophysiological mechanisms.

\subsection{Cellular Uptake of FFA by CD36 and Impairment of Calcium Concentration}

FFA uptake into the cell is mediated by fatty acid transporter, also known as cluster of differentiation (CD) 36 [65]. It is known that $\beta$-cells abundantly express CD36 [66], probably to ensure a constant FFA supply for energy allocation. CD36 does have substrate specificity, preferring long chain over medium chain FFA [67]. By the binding of long chain FFA to CD36, a pro-inflammatory response is promoted [68] inducing elevated levels of oxidative stress and cellular damage. A relief from oxidative stress can be detected by deletion of CD36 [69]. Another mechanism of FFA uptake is by binding to the free fatty acid receptor 1, also known as the G protein-coupled receptor (GPR) 40 [70]. GPR40 activates phospholipase C (PLC) [71] which is degrading phosphatidylinositol-4,5-bisphosphate into the signaling molecules inositol trisphosphate (IP3) and diacylglycerol to increase the cytosolic calcium (Ca) concentration [72]. Furthermore, Ca storages of the mitochondria are released by PLC, and the endoplasmic reticulum (ER) can release its Ca storages through the activation of GPR40 [71]. The increase of the cytosolic Ca concentration induces exocytosis of insulin vesicles [73]. The replenishment of Ca storages is facilitated by the activation of the sarcoplasmic/endoplasmic reticulum calcium ATPase (SERCA). SERCA activity is stress-sensitive and can be impaired by abundant FFA. As a result, depleted Ca storages render GSIS impossible [74], and Ca-sensitive enzymes of the tricarboxylic acid (TCA) cycle or the transport of NADH as well as the electron transport chain in mitochondria are dysregulated [73].

\subsection{Mitochondrial Uptake and Processing of FFA}

Cytosolic FFA must be activated to acyl-CoA by coenzyme A for further reactions. Acyl-CoA can be transported into the mitochondria by carnitine palmitoyltransferase (CPT) 1, also known as carnitine acyltransferase I [75]. CPT1, the key enzyme of lipid metabolism [76], will exchange the CoA residue with carnitine and initiate the transport across the outer mitochondrial membrane. The transport across the inner mitochondrial membrane is facilitated by carnitine-acylcarnitine translocase and finally, CPT2 will perform the cleavage into carnitine and acyl-CoA in the mitochondrial matrix. Acyl-CoA will be degraded through several enzymatically catalyzed steps of $\beta$-oxidation leading to the formation of acetyl-CoA and the reduction equivalents $\mathrm{NADH}$ and $\mathrm{FADH}_{2}$ [77]. Glycolysis will generate acetyl-CoA and the respective reduction equivalents. Acetyl-CoA from FFA or glucose will be used in the TCA cycle to generate more reduction equivalents.

An important biochemical feature of lipotoxicity is the impaired activity of glycolytic and TCA cycle-related enzymes with the associated ability for anaplerotic reactions. The impaired enzymes, among others the citrate synthase [78], cause a shortage of intermediates required for the TCA cycle like oxaloacetate, citrate, and $\alpha$-ketoglutarate [79], which might also be caused by a reduced activity of pyruvate carboxylase [80-82], and is also directly proportional to GSIS [83]. The gene expression of those enzymes is impaired [84], and the 
exchange of pyruvate with TCA cycle intermediates like citrate or malate is abolished and blunts GSIS [85].

\subsection{FFA-Induced Deterioration of Anaplerosis}

FFA decrease glutamine levels [86], an amino acid which supports pyruvate transport [87]. Elevated FFA are thought to influence glutamine by increasing the transformation into glutamate [88] and impairing the activity of glutamine synthetase [89]. Decreased glutamine levels further impair the function of $\beta$-cells by inhibiting cellular respiration and glucagon-like peptide 1 (GLP-1)-promoted GSIS $[86,90]$ incrementing ROS and the unfolded protein response (UPR).

Interestingly, Lee et al. reported that pyruvate carboxylase inhibition, both by phenylacetic acid (PAA) as well as by high glucose/PA treatment, mitigates AMP-activated protein kinase (AMPK), promoting apoptosis in insulinoma (INS-1) cells. By contrast, AMPK activation was protective against lipotoxic cytotoxicity. PAA and PA treatment promoted CCAAT/enhancer binding protein homologous protein (CHOP) [79] and phosphorylated c-Jun $\mathrm{N}$-terminal kinases (JNK) [91]. The activation of CHOP mediates ATP depletion, consequently reducing GSIS [92]. The reduced flux of metabolites like oxaloacetate, citrate, and $\alpha$-ketoglutarate worsens the harmful effects of lipotoxicity, whereas the reconstitution of anaplerosis alleviates the consequences of lipotoxicity, as reactions providing intermediates for TCA cycle are enhanced [79]. The authors suggest that the cause for lipotoxicity is closely related to fuel supply by TCA cycle.

In diabetic mouse models it was observed that T2DM correlates with a decreased activity of the pyruvate dehydrogenase complex [93]. This enzyme complex is necessary for glucose utilization and energy production in the TCA cycle. Glucose will be degraded to pyruvate, and through pyruvate dehydrogenase shortened to acetyl-CoA, implicating pyruvate and its related metabolic pathways exert a crucial role for the mitochondrial function [79].

\subsection{Impairment of Iron-Sulfur Cluster Biosynthesis and Ferroptosis Is Induced by FFA}

The impaired formation of iron-sulfur (Fe/S) clusters [94,95] was reported to be affected by elevated FFA. These clusters are generated in mitochondria by the iron-sulfur cluster assembly machinery (ISC) [96]. The ISC contains more than 18 proteins responsible for the formation, transfer, or insertion of $\mathrm{Fe} / \mathrm{S}$ clusters into apoproteins [97]. Fe/S clusters contribute to three-dimensional molecular structure, transfer electrons, or are enzymatic co-substrates. Some of the Fe/S enzymes are involved in energy metabolism like complex I [98], II [99], and III [100] of the respiratory chain. Other Fe/S enzymes serve as sensors for oxygen [101], are involved in gene expression [102] or lipid metabolism [103]. Aconitase, an Fe/S cluster containing enzyme, is especially interesting in this context [104]. It has different functions in the cell depending on its localization. While the mitochondrial aconitase is part of the TCA cycle, the cytosolic aconitase has a regulatory function in Fe-homeostasis and is accordingly termed iron regulatory protein 1 (IRP1) [105]. While losing its Fe/S cluster in an Fe-deficient state, IRP1 binds the iron regulatory element (IRE) of mRNA. IREs are part of the cellular iron-regulatory machinery like ferritin, transferrin receptor 1, divalent metal transporter 1, or ferroportin. By binding IRP1 to IRE, the Fe-uptake into the mitochondria is increased, thus providing more Fe for the Fe/S cluster formation. This regulation by IRP1 is highly conserved and found in yeast, plants, animals, and humans [106]. As previously shown, FFA-induced deficiency of glutaredoxin 5 (Glrx5), a protein of the ISC transferring $\mathrm{Fe} / \mathrm{S}$ clusters, disrupted the $\mathrm{Fe} / \mathrm{S}$ cluster insertion into apoproteins [94,95]. FFA-mediated cellular stress or impaired protein maturation could be detrimental for the sensitive clusters and enzymes. Consequently, enzymes of the TCA cycle and complexes of the respiratory chain act less efficiently leading to reduced production of ATP. Furthermore, the Fe-regulation by the cytosolic aconitase is impaired inducing uncontrolled Fe-uptake into the mitochondria. Mitochondrial Fe-overload in combination with elevated ROS promotes the generation of lipid peroxides leading to an Fe-dependent form of non-apoptotic 
cell death [107] called ferroptosis [60]. Glutathione peroxidase (GPx) 4 is an enzyme which has protective properties by lowering lipid peroxides in a glutathione (GSH) dependent reaction [108] thereby counteracting ferroptosis. Furthermore, FFA also deplete GSH, therefore debilitating the detoxification of lipid peroxides by GPx4 [109]. By increasing oxidative stress, FFA can induce the transformation of GSH into glutathione disulfide [110]. A lipotoxic-induced deficiency of Glrx 5 might therefore impair mitochondrial metabolism by lowering activity of TCA cycle enzymes and complexes I-III as well as the induction of $\beta$-cell decay by ferroptosis and could be correlated to lower GSIS. Glrx5 mutations have been described in seven human case reports [106,111-114], of which three describe a link to DM, ferroptosis, and impaired enzyme activities [106,112,114].

\subsection{FFA Utilization in Energy Metabolism Contributes to Oxidative Stress}

In cells with adequate oxygen supply complexes I-IV use reduction equivalents generated by acetyl-CoA to build up a proton gradient in the respiratory chain to generate ATP at complex V (ATP synthase). The electron transfer caused by complex I, complex II, and complex III will generate ROS in a reaction with oxygen [115], complex I contributing to the largest extent [116]. The excessive use of FFA or glucose for energy production will lead to an increased amount of ROS, eventually damaging the cells by reactions with molecules like DNA or enzymes or producing lipid peroxide, triggering ferroptosis.

Another way of generating ROS out of FFA is the $\beta$-oxidation in peroxisomes. Again, it is difficult to define at which specific concentrations ROS become harmful for cell physiology. It is important to note that the imbalance between ROS production and detoxification is the detrimental key factor for oxidative stress. As $\beta$-cells have reduced amounts of antioxidative enzymes, it seems likely that the threshold of an overwhelmed antioxidative defense is lower compared to other types of cells.

There are some data indicating that FFAs mediate an increasing level of toxicity depending on their carbon chain length. Especially long chain fatty acids are suspected to be preferably metabolized in peroxisomes due to specific FFA importers in mitochondria and peroxisomes while less toxic short chain and middle chain FFAs are degraded in the mitochondria [115]. Thus, a diet rich in middle chain fatty acids is not detrimental to $\beta$-cells and even promotes GSIS [117], presumably mediated through GPR40.

In human plasma, the five most abundant FFAs, namely OA, PA, stearic, linoleic, and palmitoleic acid, do have a minimum carbon chain length of 16 carbon units and belong to the group of long chain fatty acids. These represent more than $90 \%$ of the total amount of FFA in human plasma [118]. The reactions of $\beta$-oxidation in peroxisomes are mostly similar to the reactions in the mitochondria, except for the initial step that is facilitated by different enzymes. In peroxisomes the acyl-CoA oxidase will reduce FAD to $\mathrm{FADH}_{2}$ and form a double binding in the carbon chain of fatty acids. The acyl-CoA dehydrogenase will perform the same reaction in mitochondria [119]. While the electron transfer to $\mathrm{FADH}_{2}$ in mitochondria by acyl-CoA dehydrogenase can be further used for ATP production, in peroxisomes the electrons will interact with oxygen to form hydrogen peroxide $\left(\mathrm{H}_{2} \mathrm{O}_{2}\right)$. Loading with FFA leads to an increased formation of $\mathrm{H}_{2} \mathrm{O}_{2}$ in peroxisomes as compared to mitochondria [120]. $\mathrm{H}_{2} \mathrm{O}_{2}$ is membrane permeable [121] and can induce negative effects also outside of these organelles and impair insulin secretion. These observations support the hypothesis that ROS production by peroxisomal $\beta$-oxidation as well as by mitochondrial respiratory chain complexes are the major reasons for lipotoxicity. Due to a lack of the expression of catalase, GPx1, and superoxide dismutase (SOD), $\beta$-cells seem to have only weak protection against oxidative stress $[14,122]$. Other authors are raising issues that $\beta$-cells are also equipped with other antioxidant systems like proteins of the thioredoxin family making them more resistant to stress conditions as generally assumed [123].

\subsection{Uncoupling and GLP-1 Agonists Relieve Cellular Stress}

As an adaptive response to increased oxidative stress, $\beta$-cells are able to induce the expression of uncoupling protein (UCP) 2. UCP2 is a proton channel localized at the 
inner mitochondria membrane dissipating proton gradients [124]. There are four existing isoforms, while only UCP2 is occurring in $\beta$-cells [125]. Uncoupling of mitochondria in brown adipose tissue by UCP1 is known as a useful process for generating heat [126]. However, uncoupling in $\beta$-cells by UCP2 is not proven as part of thermogenesis [127]. The uncoupling in $\beta$-cells is probably a rather adaptive response to increased oxidative stress. The elevation of ROS, especially superoxide as produced by complexes I and III, is required for the upregulation of $\mathrm{UCP} 2[128,129]$. Increased $\mathrm{H}_{2} \mathrm{O}_{2}$ concentrations further activate calcium-independent phospholipase A2 $\gamma\left(\mathrm{iPLA}_{2} \gamma\right)$ and fuel UCP2 uncoupling [56]. ${ }^{i P L A} A_{2} \gamma$ alleviates oxidative stress, but it is also a phospholipid remodeling and repair factor of the inner mitochondrial membrane targeting oxidized cardiolipin. Cardiolipin is important for mitochondrial function by regulating gene expression and influencing electron transfer at the respiratory chain complexes [130]. Exendin-4, a GLP-1 agonist used in DM therapy, can increase insulin secretion and reduce $\beta$-cell apoptosis by mechanisms including acetylation of iPLA $2 \gamma[131,132]$ as well as upregulation of pancreatic and duodenal homeobox 1 (Pdx1) also known as insulin promotor factor 1 [133]. The regulation of Pdx1 is additionally mediated by a FFA induced increase of Small heterodimer partner interacting leucine zipper protein, which again increments apoptosis [134]. FFA are ligands for the peroxisome proliferator-activated receptor (PPAR), a receptor responsible for modulation of various pathways in lipid metabolism. There are three subtypes of PPAR, namely $\operatorname{PPAR} \alpha, \operatorname{PPAR} \beta / \delta$, and PPAR $\gamma$ [135]. All of these subtypes can be activated by FFA and will increase the transcription of UCP2 [4,76,136-139]. Polymorphisms in the promotor area can also lead to a deterioration of lipid metabolism leading to obesity [140].

\subsection{ATP Production Is Diminished by Uncoupling and Reduction of ATP Synthase Activity}

The promotor region of UCP2 contains a sterol regulatory element (SRE). Binding by sterol regulatory element binding protein (SREBP)-1c can increase UCP2 expression $[141,142]$. This process is promoted by FFA. Furthermore, hormone sensitive lipase, an enzyme degrading TG into FFA, activates UCP2 linking elevated FFA levels to UCP2 activation [137].

It was shown that the uncoupling of the proton gradient is dependent on the structure of FFA, and saturated FFA promote uncoupling and exert cytotoxic effects [143]. The uncoupling of the respiratory chain by UCP2 will reduce the amount of ROS, though also lowering the ATP production at complex V. FFA can also influence the ATP synthase regardless of uncoupling factors. The ATP synthase consists of two complexes, F1 and F0. While F0 will decrease the proton gradient, F1 is the catalytic complex forming ATP [144]. The F1 complex is build up by several subunits. Among these, the $\beta$-subunit has a crucial role in ATP production because of its ATP binding site. It is reported that FFA can reduce the expression of that specific subunit leading to a decreased ATP production [145]. FFA can also induce acetylation of Sirtuin, which modulates the activity of complex V [146].

\subsection{Membrane Potential Is Modulated by the Abundance of Glucose and FFA, and Impairs Insulin Secretion}

The mitochondrial membrane potential (MMP) is dependent on a sufficiently high proton gradient within the mitochondria. FFA are well known to decrease the MMP by an UCP2-induced lowered proton gradient [49]. The reduced MMP is not only linked to reduced ATP amounts and mitochondrial dysfunction, but also to the early stage of apoptosis and therefore $\beta$-cell decay [147]. A decreased MMP and a lowered cellular ATP/ADP ratio are counteracting insulin production and secretion of insulin vesicles, connecting mitochondrial function to insulin release. The uncoupling of respiratory chain complexes is a mechanism to relieve cells of oxidative stress, whereas extensive uncoupling subsides the ATP production. As the aerobic ATP production and reduced hyperpolarization of MMP is a crucial factor for inducing insulin secretion [148,149], extensive uncoupling is not favorable for $\beta$-cells. If studied in vitro, the lipotoxic effect by uncoupling of the respiratory chain is mostly seen in states of elevated glucose concentrations $[59,78]$. In a glucose-stimulated state, $\beta$-cells are more depending on ATP rendering them more vulnera- 
ble against inefficiencies of the respiratory chain activity. Further suggestions indicate, that the lipotoxic uncoupling requires a high membrane potential reached at elevated glucose levels [150]. Interestingly, the impact of different glucose concentrations is suggested to be highly dependent on the employed model. While INS-1 cells show a glucose-dependent increase in apoptosis, no such effect was detectable in mouse insulinoma 6 (MIN6) cells or cultured human islets [151]. In the screened literature, few articles were able to observe such a glucose dependency in other cell lines than INS-1 [59,116,152-156].

\subsection{PPAR Activity Is Incremented By FFA}

Glucose can decrease the action of PPAR $\alpha$ leading to limited fatty acid metabolization [138]. This so-called glucose fatty-acid cycle (Randle cycle) ensures a sufficient energy supply to the cells as lipid storages are not used for energy production if enough glucose is available and remain unaffected for phases of starvation. In general, a downregulated rate of fat metabolism with decreased FFA clearance enhances lipotoxic effects by accumulation of lipid intermediates [157] such as acyl-CoA and malonyl-CoA. The accumulation of especially long chain acyl-CoA in the cytosol induces functional impairment and apoptosis by mediating signaling effects and Ca release. Acyl-CoA interacts with $\operatorname{PPAR} \alpha$ [138] promoting apoptosis [72], uncoupling of respiratory complexes [133], and storage as TG [158], ultimately impairing GSIS [157]. Based on the acyl-CoA content of hamster islet transformed-tioguanine resistant clone 15 (HIT-T15) cells and the average distribution of cytosolic and mitochondrial mass in mouse pancreas [159], it is estimated that the cytosolic acyl-CoA concentration in rodent $\beta$-cells is $90 \mu \mathrm{M}$, while tissue concentrations are unknown [160]. Malonyl-CoA inhibits CPT1 preventing the mitochondrial uptake of acyl-CoA [156]. Yet, there are contrary conclusions regarding the influence of CPT1 in the context of lipotoxicity. While two publications indicate that mitochondrial FFA oxidation is required for lipotoxic effects and can be counteracted by the inhibition of CPT1 $[93,138]$, another study suggests that the inhibition of CPT1 has no effect on lipotoxicity [57] indicating that FFA mediate lipotoxicity independently from mitochondrial metabolism.

\subsection{The Process of Autophagy Is Disturbed by FFA}

PPAR $\gamma$ regulates the gene expression responsible for autophagy [139] and apoptosis. While low grade autophagy activity is a requirement for remodeling of damaged cellular components [161], enhanced autophagy leads to disintegration of the $\beta$-cell [162]. In case of mitochondria, this process is called mitophagy. In the first step, damaged cellular components form autophagosomes [43], which are degraded by lysosomes. The activity of lysosomes is depending on ATP needed for acidification [43]. Thereby, FFA can reduce the lysosomal activity $[163,164]$. This will lead to an accumulation of autophagosomes [161]. Additionally, FFAs can disturb the process of autophagy by lowering the expression of the mechanistic target of rapamycin (mTOR) [43] and overexpression of optic atrophy protein 1 [163] or dynamin-related protein 1 [165]. An increase in mTOR by FFAs is also related to insulin resistance [43].

\subsection{Acyl-CoA Abates Insulin Synthesis in B-Cells}

Acyl-CoA is able to degrade the proton gradient of the respiratory chain through the formation of mitochondrial permeability transition pore [166] disturbing GSIS [71]. An increase in long chain acyl-CoA can inhibit the closure of ATP-dependent potassium (K)channels $[167,168]$. Factors involved in this effect are the acyl group, the CoA component, and protein kinase C [169]. FFA can open K-channels by direct interaction [170] or as a consequence of GPR40 mediated Ca influx, which is both decreasing the ability of glucose to stimulate insulin secretion. In addition, the mRNA level of insulin is reduced by acylCoA [156] and palmitoylation $[57,171]$, as well as the interaction with hepatic nuclear factor $4 \mathrm{a}$, which could be related to uncoupling by UCP2 [45]. Some authors claim that the activation of FFA into acyl-CoA is one of the most essential aspects mediating harmful 
effects as the inhibition of acyl-CoA synthase could suppress lipotoxicity-mediated cell death $[172,173]$.

\subsection{Ceramides Increase Oxidative Stress through Inducible Nitric Oxide Synthase}

Palmitoyl-CoA, the activated form of PA, is substrate for the de novo formation of ceramides and upregulates sphingosine kinase 2 (SK2), a key enzyme of ceramide synthesis. Ceramides have impact on various pathways including proliferation, differentiation, growth arrest, and apoptosis $[174,175]$. They can impair insulin sensitivity by protein kinase C [138] and phosphorylation of insulin receptor substrate 1 (IRS-1) [176] as well as reduce insulin expression by Pdx1 [78]. IRS-1, which is likewise regulated by SREBP1c [153], is integrated in proliferation signals by PI3K and Akt, while Akt also regulates glucose uptake by GLUT4. Furthermore, ceramides disrupt the acetylation of proteins of the mitochondrial metabolism [177], inhibit complex III, and decrease MMP [42]. They increase cellular oxidative stress through the activity of inducible nitric oxide synthase (iNOS) producing nitrogen oxide $[57,79,139,178,179]$ and NADPH oxidase 2 (NOX2) producing superoxide $[55,178,180-182]$. The activation of both iNOS and NOX2 induces apoptosis by damaging mitochondrial DNA [155], which is more susceptible to harm due to the absence of introns [179]. Damaged DNA can be recognized by stimulator of interferon genes (STING), increasing inflammation and apoptosis. The STING pathway is enhanced under lipotoxic conditions and activates interferon regulatory factor 3 [47]. It has been shown that the presence of ceramides is crucial for the induction of apoptosis. While the regulation of mitogen-activated protein kinase (MAPK) pathway including JNK and extracellular-signal-regulated kinase (ERK) as well as Pi3K/Akt pathway are undoubtedly essential for cell survival, there are contrasting data regarding their exact role for the $\beta$-cell. According to literature, effects differ crucially between cell types and highly depend on the chosen treatment conditions [132,183], e.g., PA inhibited ERK and induced apoptosis in INS-1 cells [184], but exposure of glucose and interleukin (IL)- $1 \beta$ triggered apoptosis concomitant with elevated ERK levels in human $\beta$-cells [44,185].

Additionally, SK2 was reported to increase apoptosis through Bcl-2, while SK2 inhibition prevented lipotoxic cell death [186]. The regulation of apoptosis by ceramides is seen as one of the most important factors for $\beta$-cell decay mediated by lipotoxicity [187]. While unsaturated FFA are not able to increase ceramides [188], other data indicate facilitated ceramide production through an increased $\omega 6: \omega 3$ ratio of fatty acids [189].

\subsection{Augmented Apoptosis in B-Cells by Long-Chain and Saturated FFAs}

The initiation and execution of the mitochondrial apoptosis pathway is complex and highly regulated. Briefly, the membrane of damaged cells starts to permeabilize, which is enhanced by Bax or p53-upregulated modulator of apoptosis and suppressed by Bcl-2 [190]. The permeabilization is promoted by several stress markers related to the ER, like CHOP, or the activating transcription factor [191]. The release of pro-apoptotic factors eventually triggers downstream caspases like caspase 3 . In consequence, chromatin will condensate, DNA will be fragmented, and apoptosis is executed. Particularly long chain and saturated FFA as opposed to intermediate chain length and unsaturated FFAs induce ER stress [64] and counteract protective factors such as Sirtuin3 [44,91]. The fragmentation of DNA is further promoted by oxidative stress sensitive transient receptor potential melastatin-2 channels, inducible by lipotoxicity [55].

\section{Positive Effects of FFA on $\beta$-Cell Function}

The number of articles reporting beneficial effects of FFA to $\beta$-cells and insulin secretion is remarkably low. Most intriguingly, they share the same underlying pathways as detrimental effects. Although this seems to pose a contradiction at first, a more detailed look into the respective methodologies can give possible explanations.

FFA concentrations employed in studies delivering evidence for a beneficial impact were notably lower $[71,170,171,192]$. While publications reporting detrimental effects of 
FFA usually applied concentrations around $500 \mu \mathrm{M}$, favorable effects were reported with concentrations far below $100 \mu \mathrm{M}$. Furthermore, shorter treatment times were associated with positive results indicating a difference between the acute and chronic exposure to FFA. Acute effects were observed after a few hours of treatment while chronic effects were noticeable after at least $24 \mathrm{~h}$. Exposure of INS-1 cells to $100 \mu \mathrm{M}$ for several weeks severely blunted their insulin secretion $(-80 \%)$ [49], whereas it was promoted by $1 \mathrm{~h}$ incubation with $150 \mu \mathrm{M}$ PA [56]. The short time treatment with low FFA concentration led to the activation of PPAR $\gamma$ coactivator $1 \alpha / \beta$ [193] and a depletion of Ca storages by GPR40, mediating insulin release [170]. The so-called "fatty acid stimulated insulin secretion" (FASIS) is induced by acute FFA uptake and oxidation through the activation of cellular energy production [72,158,194]. Resulting physiological low concentrations of ROS are also promoting insulin secretion, which is referred to as "redox stimulated insulin secretion" (RSIS) [56]. This effect is explained by PTEN-induced kinase 1 (PINK1)mediated autophagy activation, which is improving net insulin release pattern by disposal of damaged cells [162]. In contrast, chronic elevation of FFA exerts a detrimental impact on insulin secretion through permanent depletion of Ca-storages, and an abundance of ROS.

Another decisive aspect in lipotoxicity is the homeostasis between FFA and fat storage mobilization. The available data indicate that stored neutral TG do not act lipotoxic in contrast to FFA [195]. Therefore, it is crucial to differentiate between an energy surplus leading to an excess of FFA on one hand and a storage as neutral TG on the other hand. While adipocytes have a nearly unlimited TG storing capacity, fat storing in $\beta$-cells is limited $[195,196]$. There are some articles implying that unsaturated FFA promote TG storage, thereby counteracting the toxic effect of saturated FFA [195,197]. Other authors assume that the protective effect is independent from fat storage [198], but rather reliant on a positive effect of unsaturated FFA to proapoptotic factors [46], while also inducing mitochondrial apoptosis [199]. Further data suggest an anti-lipotoxic effect of unsaturated FFA [200]. However, the underlying mechanisms have not yet been elucidated. Unsaturated FFA reveal their anti-lipotoxic effect mainly in co-treatment with saturated FFA. As sole treatment with unsaturated FFA is also toxic, enhanced lipid storing by unsaturated FFA should be further investigated as protective mechanism. It has been shown that the amount of unbound FFA is a better parameter for lipotoxicity instead of total concentration of FFA [57]. A summary of beneficial effects to $\beta$-cell physiology can be found in Table 6 . 
Table 6. Summary of metabolic effects of FFA treatment and respective pathways. Palmitic acid (PA). Insulinoma (INS1). Glucose-stimulated insulin secretion (GSIS). Adenosine triphosphate (ATP). Calcium (Ca). Free fatty acids (FFA). Hamster islet transformed-tioguanine resistant clone 15 (HIT-T15). Phospholipase C (PLC). Endoplasmic reticulum (ER). Peroxisome proliferator-activated receptor (PPAR). Institute for Cancer Research (ICR). Chinese hamster ovary (CHO). Human embryonic kidney 293 (HEK 293). Hepatoblastoma (HepG2). Mouse insulinoma 6 (MIN6). Uncoupling protein (UCP). G protein-coupled receptor (GPR). PTEN-induced kinase 1 (PINK1). Oleic acid (OA). Triglyceride (TG).

\begin{tabular}{|c|c|c|c|}
\hline Article & Treatment & Model & $\begin{array}{l}\text { Results and Respective } \\
\text { Pathways }\end{array}$ \\
\hline Green et al., 2009 [192] & $50 \mu \mathrm{M}$ PA, $1 \mathrm{~h}$ & INS- 1 cells, human islets & $\begin{array}{ll}\text { - } & \text { liver } X \text { receptor improved GSIS } \\
- & \beta \text {-oxidation provided ATP for GSIS } \\
- & \text { lipid signaling supported Ca influx }\end{array}$ \\
\hline $\begin{array}{l}\text { Komatsu et al., } 1999 \\
{[171]}\end{array}$ & $10 \mu \mathrm{M}$ PA, $1 \mathrm{~h}$ & Wistar Rat islets & FFA supported GSIS within first $10 \mathrm{~min}$ of secretion \\
\hline $\begin{array}{l}\text { Remizov et al., } 2003 \\
\text { [170] }\end{array}$ & $\begin{array}{l}100 \mu \mathrm{M} \text { PA, } \\
30-60 \mathrm{~min}\end{array}$ & HIT-T15 cells, primary mice $\beta$-cells & FFA caused Ca mobilization from internal storages \\
\hline Zhao et al., 2013 [71] & $\begin{array}{l}20 \mu \mathrm{M} \text { linoleic acid, } \\
2-10 \mathrm{~min}\end{array}$ & Sprague Dawley rat islets & $\begin{array}{l}\text { - FFA stimulated Ca increase. Effect depended on } \\
\text { Acyl-CoA synthase, PLC, and ER/mitochondrial Ca } \\
\text { storages }\end{array}$ \\
\hline $\begin{array}{c}\text { Oropeza et al., } 2015 \\
\text { [193] }\end{array}$ & $100 \mu \mathrm{M} \mathrm{PA}, 1 \mathrm{~h}$ & C57BL/6J mice islets & $\begin{array}{l}\text { FFA increased PPAR } \gamma \text { coactivator } 1 \alpha \text { expression, } \\
\text { regulating key enzymes in lipolysis and the } \\
\text { glycerolipid/free fatty acid cycle }\end{array}$ \\
\hline Chen et al., 2020 [72] & $10 \mu \mathrm{M}$ linolenic acid, $1 \mathrm{~h}$ & $\begin{array}{l}\text { INS-1 cells, } \mathrm{KO} \text { mice islets, Wistar Rat } \\
\text { islets }\end{array}$ & $\begin{array}{l}\text { FFA receptor } 1 \text { agonist supported insulin secretion } \\
\text { by increased mitochondrial function and } \\
\beta \text {-oxidation }\end{array}$ \\
\hline Li et al., 2020 [194] & $10 \mu \mathrm{M}$ linolenic acid, $1 \mathrm{~h}$ & $\begin{array}{l}\text { ob/ob mice, ICR mice, C57BL/ } 6 \text { mice, } \\
\text { CHO cells, HEK293 cells, HepG2 cells, } \\
\text { MIN6 cells }\end{array}$ & $\begin{array}{l}\text { FFA receptor } 1 \text { agonist supported insulin secretion } \\
\text { and glycemic control }\end{array}$ \\
\hline Li et al., 2020 [158] & No FFA & $\begin{array}{l}\text { C57BL/6 mice, ob/ob mice, } \mathrm{db} / \mathrm{db} \\
\text { mice }\end{array}$ & $\begin{array}{l}\text { FFA receptor 1/PPAR agonist supported } \beta \text {-cell } \\
\text { function and fatty acid metabolism }\end{array}$ \\
\hline Ježek et al., 2015 [56] & $150 \mu \mathrm{M} \mathrm{PA}, 1 \mathrm{~h}$ & INS-1 cells & $\begin{array}{l}\text { - } \quad \text { FFA activated UCP2. Oxidative stress by } \\
\text { physiological FFA uptake was prevented. } \\
\text { - } \quad \text { PA increased insulin secretion by GPR40 }\end{array}$ \\
\hline Guo et al., 2019 [162] & $\begin{array}{l}100-500 \mu \mathrm{M} \text { PA, } \\
24-48 \mathrm{~h}\end{array}$ & RIN-m5f cells & $\begin{array}{l}\text { sonodynamic therapy increased insulin secretion of } \\
\text { damaged cells by activated PINK1 autophagy }\end{array}$ \\
\hline Cho et al., 2012 [195] & $\begin{array}{c}100-500 \mu \mathrm{M} \text { PA, } 24 \mathrm{~h} \text { and } \\
10-62 \mu \mathrm{M} \text { arachidonic acid and } \\
20-120 \mu \mathrm{M} \text { unsaturated FFA } \\
\text { (OA, arachidonic acid, } \\
\text { palmitoleic acid) }\end{array}$ & HIT-T15 cells & $\begin{array}{l}\text { unsaturated fatty acids protected against PA } \\
\text { damages, probably by TG accumulation }\end{array}$ \\
\hline Tuo et al., 2011 [199] & 50-500 $\mu \mathrm{M}$ linoleic acid, $48 \mathrm{~h}$ & INS-1 cells & $\begin{array}{l}\text { negative effects occurred from } 250 \mu \mathrm{M} \text { upwards for } \\
\text { viability, effect depended on high glucose } \\
\text { concentrations }\end{array}$ \\
\hline Ježek et al., 2018 [200] & $\begin{array}{l}100 \mu \mathrm{M} \mathrm{PA} \\
10-60 \mathrm{~min}\end{array}$ & C57BL6J mice islets & $\begin{array}{l}\text { monoacylglycerol bound to GPR119 and enhanced } \\
\text { insulin secretion }\end{array}$ \\
\hline Cnop et al., 2001 [57] & $\begin{array}{l}125-500 \mu \mathrm{M} \text { PA and OA, } 2 \mathrm{~d} \\
\text { and } 8 \mathrm{~d}\end{array}$ & Wistar Rat islets & $\begin{array}{l}\text { OA treatment accumulated more TG than PA, } \\
\text { ameliorating the detrimental effects of FFA }\end{array}$ \\
\hline
\end{tabular}

\section{Influence of Ageing on $\beta$-Cell Function}

Since there are multiple mechanisms by which lipotoxicity can impair $\beta$-cell function, this section will review which of the underlying pathways are especially related to accelerated ageing and senescence of $\beta$-cells and the pancreas. Cellular senescence is defined by a cell cycle arrest triggered by damaged DNA, exerting an anti-tumorigenic purpose [201]. It can be induced due to telomere shortening at the end of a cell's life span, or, dependent on the physiological conditions, as part of the cellular stress response. Lipotoxicity is linked to cellular senescence by the p38 MAPK pathway which is age-dependently correlating 
with decreased cell proliferation and insulin release in $\beta$-cells. Lipotoxicity can contribute to the activation of p38 MAPK by elevated ROS and ceramides. p38 MAPK promotes senescence through different pathways, which are dependent on and independent of telomerase length [202]. As autophagy can be regulated by MAPK, it is tempting to speculate that lipotoxicity might thereby impair the degradation of damaged organelles and cellular regeneration. Age-dependently, ROS and levels of radicals tend to accumulate and lead to enhanced damaging of mitochondrial proteins and DNA, leading to cellular dysfunction. Beside cellular damaging and signal pathways, glucose and insulin homeostasis is impaired by decline in mitochondrial ATP synthesis capacity and reduced expression and translocation of GLUT2 [117]. In addition, depending on age, the insulin dependent uptake by GLUT4 is decreased by Ras-related C3 botulinum toxin substrate 1 (Rac1), a protein which is correlating with ceramide-mediated senescence [203]. In presence of ceramides, the activation of Rac1 could also influence oxidative stress by induction of NOX2 [178]. With increasing age, the activity of insulin like growth factor (IGF) binding protein 3 as well as the total amount of IGF decline. A reduced binding of IGF leads to the deterioration of glucose tolerance, lipid metabolism, and increased stress by absent UCP regulation [204]. FFA can further have negative effects on the activity of the subunits of farnesyl transferase (FTase) and geranylgeranyl transferase (GGTase). FTase and GGTase are enzyme complexes required for the prenylation of proteins determining localization and transport of proteins. The degradation of subunits of FTase and GGTase by FFA activation of caspase is chronically activating Rac1 leading to increased cellular stress. The impairment of protein prenylation has negative consequences on GSIS and is connected to ageing syndromes [180]. A further increase of senescence has been seen in involving caveolin-1, a membrane protein inducing apoptosis by Src family kinases-mediated phosphorylation of tyrosine-14, which is promoted by FFA [42]. While they are known ways, how lipotoxicity is correlating with acceleration of $\beta$-cell senescence, the data in this literature search are limited to few articles $(n=15)$.

\section{Potential Protective Effects of Plant-Based Nutrients}

A healthy lifestyle involving sufficient exercise and a balanced diet is a pivotal part of the treatment of T2DM. Plant-based nutrients as mainly recommended in the so-called Mediterranean diet contain numerous phytochemicals mediating wholesome effects. In particular, the major group of polyphenols was reported to wield protective properties, e.g., ameliorating glucotoxicity [205,206], oxidative stress [207], and ER stress [208] as well as inhibiting $\alpha$-amylase $[209,210]$ and preventing protein glycation [211]. Yet, their effects on the mitochondria of $\beta$-cells have been barely investigated (in cell lines: $n=5$, in animal experiments: $n=5$ ). Most interestingly, the beneficial effects of polyphenols are targeting pathways affected by lipotoxicity. They counteract the dysregulation of the MAPK and Pi3K pathway [22,23,212-214], and mitigate apoptosis by altering Bax/Bcl ratio and up-regulation of $\mathrm{Pdx} 1$, protein kinase $\mathrm{A}$, and cAMP response element-binding protein signaling [215]. They stabilize the mitochondrial membrane preventing the release of proapoptotic factors and enhancing Ca signaling [23]. Moreover, polyphenols support insulin release through interaction with $\mathrm{Pdx1}$ [212] in a forkhead box protein $\mathrm{O} 1$ (FoxO1)-dependent manner [214] and inhibit dipeptidylpeptidase-4 (DPP4) to increase GLP-1 levels-a pathway successfully used in clinical practice by DPP4 inhibitors and GLP-1 receptor agonists $[33,216,217]$. In addition, the dysregulation of GLUT2 and GLUT4 can be reversed by polyphenols improving elevated blood glucose levels and increasing insulin sensitivity [22]. Furthermore, relief from oxidative stress due to their radical scavenging capacity [33], and amelioration of ROS production by iNOS was reported. Polyphenols promote the activity and regeneration of antioxidative enzymes like SOD, catalase, GSH reductase, and GPx [21,33,212,218]. Particularly, GPx4 reduces lipid peroxides in the context of ferroptosis. As lipotoxicity-induced ferroptosis is also closely related to restrictions of Fe/S enzymes, plant-based nutrients rich in polyphenols were shown to sustain the activity of those enzymes, e.g., cytochrome $\mathrm{C}$ oxidase or succinate dehydrogenase, which 
showed lowered activity in an animal study with high fat diet [212] counteracting mitochondrial dysfunction. Possible beneficial effects of polyphenols could be also mediated by improved fat metabolism through upregulation of SREBP-1c including signals from Akt or the estrogen receptor $\alpha[22,23]$ and lipid storing, improving lipid parameters [21,218]. Polyphenols further exert anti-inflammatory effects through decreased cytokine levels and ER stress [212,219].

According to these data, plant-based nutrients rich in polyphenols might be promising agents to counteract lipotoxic damage to $\beta$-cell mitochondria in diabetes and account for the beneficial effects of the Mediterranean diet. Yet, their clinical and therapeutical benefit has not been studied in clinical trials, and some authors even claim that toxic effects might arise from dosages required to achieve therapeutic levels in humans [33]. A summary of the described effects is given in Table 7.

Table 7. Summary of metabolic effects mediated by plant-based polyphenols and respective pathways. Oleic acid (OA). Mouse insulinoma 6 (MIN6). Glutathione peroxidase (GPx). Free fatty acids (FFA). Glucagon-like peptide 1 (GLP-1). Dipeptidylpeptidase-4 (DPP4). Reactive oxygen species (ROS). Superoxide dismutase (SOD). Triglyceride (TG). Palmitic acid (PA). Insulinoma (INS-1). Pancreatic and duodenal homebox 1 (Pdx1). Extracellular-signal-regulated kinase (ERK). Glucose-stimulated insulin secretion (GSIS). Endoplasmic reticulum (ER). Insulin receptor substrate 1 (IRS-1). Glucose transporter (GLUT). Rat insulinoma (Rinm5f). AMP-activated protein kinase (AMPK). Mechanistic target of rapamycin (mTOR). High fat diet (HFD). Interleukin (IL). Tumor necrosis factor $\alpha$ (TNF $\alpha$ ). Forkhead box protein O1 (FoxO1).

\begin{tabular}{|c|c|c|c|c|}
\hline Article & Treatment & Model & Extract, Substance & $\begin{array}{c}\text { Results and Respective } \\
\text { Pathways }\end{array}$ \\
\hline $\begin{array}{l}\text { Zakłos-Szyda et al., } \\
2020 \text { [33] }\end{array}$ & $100 \mu \mathrm{M}$ OA, $24 \mathrm{~h}$ & MIN6 cells & $\begin{array}{l}\text { Viburnum opulus L., fresh juice } \\
\text { and phenolic rich fraction with } \\
\text { chlorogenic acid, flavanols, } \\
\text { procyanidins }\end{array}$ & 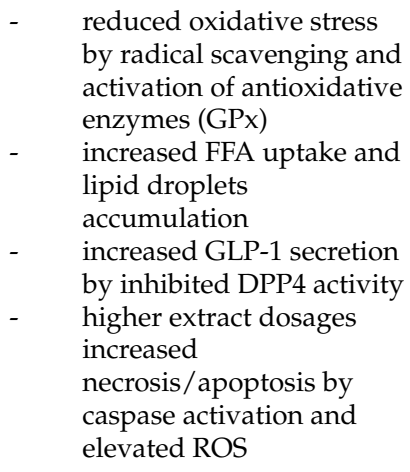 \\
\hline $\begin{array}{l}\text { Renganathan et al., } \\
2020 \text { [21] }\end{array}$ & No induction & Wistar rats & $\begin{array}{l}\text { Dhanwantaram kashayam, } \\
\text { polyherbal formulation } \\
\text { containing Sida spinosa L., } \\
\text { Hordeum vulgare L., Aegle } \\
\text { marmelos (L.) Corrêa, Bauhinia } \\
\text { forficata Link. }\end{array}$ & $\begin{array}{l}\text { - less oxidative stress by } \\
\text { activation of antioxidative } \\
\text { enzymes (catalase, SOD, } \\
\text { GPx, glutathion reductase) } \\
\text { improved lipid } \\
\text { parameters (total } \\
\text { cholesterol, FFA, } \\
\text { phospholipids, TG) } \\
\text { extract abated } \\
\text { antioxidative enzymes in } \\
\text { control rats }\end{array}$ \\
\hline
\end{tabular}


Table 7. Cont.

\begin{tabular}{|c|c|c|c|c|}
\hline Article & Treatment & Model & Extract, Substance & $\begin{array}{l}\text { Results and Respective } \\
\text { Pathways }\end{array}$ \\
\hline Liu et al., 2019 [34] & $\begin{array}{l}200 \mu \mathrm{M} \mathrm{PA} \\
24-96 \mathrm{~h}\end{array}$ & $\begin{array}{l}\text { INS- } 1 \text { cells, C57BL/6J } \\
\text { mice islets }\end{array}$ & Dracorhodin perchlorate & $\begin{array}{ll}\text { - } & \text { increased Pdx1 expression } \\
\text { by ERK1/2 } \\
\text { - } & \text { decreased apoptosis by } \\
\text { Bax/Bcl-2 ratio } \\
\text { - } \quad \text { lowered blood glucose by } \\
\text { improved GSIS, increased } \\
\text { islet size } / \text { number } \\
\text { diminished ER stress }\end{array}$ \\
\hline Sun et al., 2019 [23] & $100 \mu \mathrm{M}$ PA, $48 \mathrm{~h}$ & INS-1 cells & Silibinin & $\begin{array}{l}\text { - } \\
\text { limproved viability, GSIS, } \\
\text { estrogen receptor } \\
\text { increased mitochondrial } \\
\text { mass and improved } \\
\text { mitochondrial membrane } \\
\text { potential }\end{array}$ \\
\hline $\begin{array}{c}\text { Gharib and } \\
\text { Montasser Kouhsari, } \\
2019 \text { [22] }\end{array}$ & No induction & Wistar rats & $\begin{array}{l}\text { Punica granatum L., fruit extract } \\
\text { with punicalagin, } \\
\text { anthocyanins, ellagic acid, gallic } \\
\text { acid, caffeic acid, } \\
\text { catechins, quercetin, rutin }\end{array}$ & 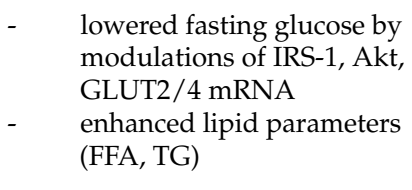 \\
\hline $\begin{array}{c}\text { Gharib et al., } 2018 \\
\text { [213] }\end{array}$ & No induction & Wistar rats & $\begin{array}{l}\text { Punica granatum L., fruit extract } \\
\text { with punicalagin, } \\
\text { anthocyanins, ellagic acid, gallic } \\
\text { acid, caffeic acid, } \\
\text { catechins, quercetin, rutin }\end{array}$ & $\begin{array}{ll}\text { - } & \text { improved lipid parameters } \\
\text { (FFA, TG) } \\
\text { - } \\
\text { increased insulin sensitiv- } \\
\text { ity by decreased p53, p65, } \\
\text { miR-145 and elevated IRS- } \\
1 \\
\text { - } \quad \text { reduced ROS }\end{array}$ \\
\hline $\begin{array}{l}\text { Huang et al., } 2017 \\
\text { [216] }\end{array}$ & $100 \mu \mathrm{M}$ PA, $24 \mathrm{~h}$ & RINm5F cells & $\begin{array}{c}\text { Abelmoschus esculentus (L.) } \\
\text { Moench, extract with quercetin } \\
\text { glucosides, pentacyclic } \\
\text { triterpene ester, } \\
\text { carbohydrates, polysaccharides }\end{array}$ & $\begin{array}{l}\text { - } \quad \text { increased GLP-1 effect by } \\
\text { decreased DPP4 activity } \\
\text { reduced apoptosis by } \\
\text { AMPK, mTOR, PI3K } \\
\text { signaling }\end{array}$ \\
\hline Liu et al., 2017 [212] & HFD, 6 weeks & $\begin{array}{l}\text { Sprague dawley rats } \\
\text { islets }\end{array}$ & $\begin{array}{l}\text { Morus nigra L., leaf extract with } \\
\text { polysaccharides }\end{array}$ & $\begin{array}{ll}\text { - } & \text { improved lipid } \\
\text { parameters (FFA, TG, } \\
\text { low-density lipoprotein) } \\
\text { - } & \text { decreased IL-6, TNF } \alpha \\
- & \text { lowered fasting glucose } \\
- & \text { promoted mitochondrial } \\
\text { enzymes (succinate } \\
\text { dehydrogenase, } \\
\text { cytochrome C oxidase) } \\
\text { morphological } \\
\text { improvement of } \beta \text {-cells }\end{array}$ \\
\hline $\begin{array}{l}\text { Hao et al., } 2015 \\
\text { [214] }\end{array}$ & $500 \mu \mathrm{M}$ PA, $24 \mathrm{~h}$ & MIN6 cells & Curcumin & $\begin{array}{ll}\text { - } & \text { reduced apoptosis by } \\
\text { caspase and Bax/Bcl-2 } \\
\text { ratio } \\
\text { improved GSIS by } \\
\text { mitochondrial membrane } \\
\text { potential, Akt, FoxO1 } \\
\text { reduced oxidative stress } \\
\text { by antioxidative enzymes } \\
\text { (MnSOD, catalase, GPx, } \\
\text { glutathione reductase) }\end{array}$ \\
\hline
\end{tabular}




\section{Conclusions}

Mitochondrial function is a key parameter crucially determining energy supply and cell survival. By those factors, it plays a central role in $\beta$-cell decay and development of T2DM. FFAs are well known to impair the glucose metabolism by mediating negative effects on mitochondria generally known as lipotoxicity. As lipotoxicity is multifactorial, most of the reviewed studies described lipotoxic effects mediated by increased oxidative stress, uncoupling of energy production by $\mathrm{UCP} 2$, deterioration of lipid homeostasis by PPAR and SREBP-1c signaling, extra-mitochondrial signaling through accumulation of acyl-CoA, and eventually enhanced apoptosis. While lipotoxicity can accelerate senescence of $\beta$-cells, there is evidence for a sustained mitochondrial metabolism and reversed effects of lipotoxicity by polyphenols as apparent in plant-based nutrients. However, the data are extremely limited and covering a wide range of different plants and ingredients, preventing a distinct verdict on their significance for T2DM and lipotoxicity. When studying the effects of FFAs, parameters like structure, concentration, treatment duration, and preparation should be considered carefully since they have massive impact on the outcome of the experimental setup. Especially the employed concentration substantially determines if FFAs will have an adverse or beneficial effect on $\beta$-cells. Judging cautiously from literature it can be generally assumed that in vitro FFAs mediate physiological effects in the lower micromolar range (Table 6), whereas concentrations in the upper micromolar range and higher exert lipotoxic effects. In contrast, concentrations are considerably higher in vivo with human serum containing levels in the lower millimolar range and murine serum with approximately $10 \%$ of this amount.

The different results of FFAs and polyphenol treatment as well as the multifactorial presentation of lipotoxicity leaves several questions unanswered. Therefore, further studies with clearly defined experimental setups would benefit this promising field of research and further elucidate the execution of lipotoxicity and respective protective mechanisms for the pancreatic $\beta$-cell.

Supplementary Materials: The following are available online at https:/ /www.mdpi.com/2076-392 1/10/2/293/s1; Supplement S1: Articles included after literature search on PubMed $(n=130)$.

Author Contributions: A.R.: conceptualization, methodology, original draft preparation, and visualization. T.L.: conceptualization, critical review, and editing. S.F.P.: conceptualization, critical review, editing, and supervision. All authors have read and agreed to the published version of the manuscript.

Funding: This research received no external funding.

Conflicts of Interest: The authors declare no conflict of interest.

\section{Abbreviations}

AMPK, AMP-activated protein kinase; ATG7, Ubiquitin-like modifier-activating enzyme; ATP, adenosine triphosphate; $\mathrm{BSA}$, bovine serum albumin; $\beta \mathrm{TC} 6, \beta$-tumour cell; $\mathrm{Ca}$, calcium; $\mathrm{CD}$, cluster of differentiation; $\mathrm{CHO}$, Chinese hamster ovary; $\mathrm{CHOP}, \mathrm{CCAAT} /$ enhancer binding protein homologous protein; COS1, CV-1 in origin simain-1; CPT, carnitine palmitoyltransferase; DM, diabetes mellitus; DPP4, dipeptidylpeptidase-4; ER, endoplasmic reticulum; ERK, extracellular-signal-regulated kinase; FASIS, fatty acid stimulated insulin secretion; Fe/S, iron-sulfur; FFA, free fatty acids; FoxO1, forkhead box protein O1; FTase, farnesyl transferase; GGTase, geranylgeranyl transferase; GLP-1, glucagon-like peptide 1; Glrx5, glutaredoxin 5; GLUT, glucose transporters; GPR, G protein-coupled receptor; GPx, glutathione peroxidase; GSH, glutathione; GSIS, glucose-stimulated insulin secretion; $\mathrm{H}_{2} \mathrm{O}_{2}$, hydrogen peroxide; HcB19, TXNIP deficiency; HEK 293, Human embryonic kidney 293; HepG2, Hepatoblastoma; HFD, high fat diet; HIT-T15, Hamster islet transformed-tioguanine resistant clone 15; ICR, Institute for Cancer Research; IGF, insulin like growth factor; IL, interleukin; iNOS, inducible nitric oxide synthase; INS-1, insulinoma; IP3, inositol trisphosphate; iPLA $2 \gamma$, calciumindependent phospholipase A2 $\gamma$; IRE, iron regulatory element; IRP1, iron regulatory protein 1 ; IRS-1, insulin receptor substrate 1; ISC, iron-sulfur cluster assembly machinery; JNK, phosphorylated 
c-Jun N-terminal kinases; K, potassium; KK-Ay, Diabetic KK and lethal yellow (Ay) mice; MAPK, mitogen-activated protein kinase; MIN6, Mouse insulinoma 6; MMP, mitochondrial membrane potential; mTOR, mechanistic target of rapamycin; NIT1, NOD/Lt; NMRI, Naval Medical Research Institute; NOX2, NADPH oxidase 2; OA, oleic acid; PA, palmitic acid; PAA, phenylacetic acid; Pdx1, pancreatic and duodenal homebox 1; PINK1, PTEN-induced kinase 1; PLC, phospholipase C; PPAR, peroxisome proliferator-activated receptor; Rac1, Ras-related C3 botulinum toxin substrate 1; Rinm5f, Rat insulinoma; ROS, reactive oxygen species; RSIS, redox stimulated insulin secretion; SERCA, sarcoplasmic/endoplasmic reticulum calcium ATPase; SK2, sphingosine kinase 2; SOD, superoxide dismutase; SRE, sterol regulatory element; SREBP, sterol regulatory element binding protein; STING, stimulator of interferon genes; T2DM, type 2 diabetes mellitus; TCA, tricarboxylic acid; TG, triglyceride; TNF $\alpha$, tumor necrosis factor $\alpha$; UCP, uncoupling protein; UPR, unfolded protein response.

\section{References}

1. Saeedi, P.; Petersohn, I.; Salpea, P.; Malanda, B.; Karuranga, S.; Unwin, N.; Colagiuri, S.; Guariguata, L.; Motala, A.A.; Ogurtsova, K.; et al. Global and regional diabetes prevalence estimates for 2019 and projections for 2030 and 2045 : Results from the International Diabetes Federation Diabetes Atlas, 9th edition. Diabetes Res. Clin. Pract. 2019, 157, 107843. [CrossRef] [PubMed]

2. Kawahito, S.; Kitahata, H.; Oshita, S. Problems associated with glucose toxicity: Role of hyperglycemia-induced oxidative stress. World J. Gastroenterol. 2009, 15, 4137. [CrossRef]

3. Sato, Y.; Endo, H.; Okuyama, H.; Takeda, T.; Iwahashi, H.; Imagawa, A.; Yamagata, K.; Shimomura, I.; Inoue, M. Cellular hypoxia of pancreatic $\beta$-cells due to high levels of oxygen consumption for insulin secretion in vitro. J. Biol. Chem. 2011, 286, 12524-12532. [CrossRef]

4. Jiang, L.; Wan, J.; Ke, L.Q.; Lü, Q.G.; Tong, N.W. Activation of PPAR $\delta$ promotes mitochondrial energy metabolism and decreases basal insulin secretion in palmitate-treated $\beta$-cells. Mol. Cell. Biochem. 2010, 343, 249-256. [CrossRef] [PubMed]

5. Reaven, G.M.; Hollenbeck, C.; Jeng, C.Y.; Wu, M.S.; Chen, Y.D.I. Measurement of plasma glucose, free fatty acid, lactate, and insulin for $24 \mathrm{~h}$ in patients with NIDDM. Diabetes 1988, 37, 1020-1024. [CrossRef] [PubMed]

6. Bikopoulos, G.; da Silva Pimenta, A.; Lee, S.C.; Lakey, J.R.; Der, S.D.; Chan, C.B.; Ceddia, R.B.; Wheeler, M.B.; Rozakis-Adcock, M. Ex vivo transcriptional profiling of human pancreatic islets following chronic exposure to monounsaturated fatty acids. $J$. Endocrinol. 2008, 196, 455-464. [CrossRef] [PubMed]

7. Salgin, B.; Ong, K.K.; Thankamony, A.; Emmett, P.; Wareham, N.J.; Dunger, D.B. Higher fasting plasma free fatty acid levels are associated with lower insulin secretion in children and adults and a higher incidence of type 2 diabetes. J. Clin. Endocrinol. Metab. 2012, 97, 3302-3309. [CrossRef] [PubMed]

8. Ye, R.; Onodera, T.; Scherer, P.E. Lipotoxicity and B cell maintenance in obesity and type 2 diabetes. J. Endocr. Soc. 2019, 3, 617-631. [CrossRef]

9. Boden, G. Effects of Free Fatty Acids (FFA) on Glucose Metabolism: Significance for Insulin Resistance and Type 2 Diabetes. Exp. Clin. Endocrinol. Diabetes 2003, 111, 121-124. [CrossRef]

10. Kushner, J.A. The role of aging upon $\beta$ cell turnover. J. Clin. Investig. 2013, 123, 990-995. [CrossRef]

11. Kalyani, R.R.; Golden, S.H.; Cefalu, W.T. Diabetes and aging: Unique considerations and goals of care. Diabetes Care 2017, 40, 440-443. [CrossRef]

12. Spitler, K.M.; Davies, B.S.J. Aging and Plasma Triglyceride Metabolism. J. Lipid Res. 2020, 61, 1161-1167. [CrossRef] [PubMed]

13. Houtkooper, R.H.; Argmann, C.; Houten, S.M.; Cant'o, C.; Jeninga, E.H.; Andreux, P.A.; Thomas, C.; Doenlen, R.; Schoonjans, K.; Auwerx, J. The metabolic footprint of aging in mice. Sci. Rep. 2011, 1, 1-11. [CrossRef]

14. Lei, X.G.; Vatamaniuk, M.Z. Two Tales of Antioxidant Enzymes on $\beta$ Cells and Diabetes. Antioxid. Redox Signal. 2011, 14, 489-503. [CrossRef]

15. Okoduwa, S.I.R.; Umar, I.A.; Ibrahim, S.; Bello, F.; Habila, N. Age-dependent alteration of antioxidant defense system in hypertensive and type-2 diabetes patients. J. Diabetes Metab. Disord. 2015, 14. [CrossRef]

16. Rupasinghe, H.P.V.; Balasuriya, N.; Wang, Y. Prevention of Type 2 Diabetes by Polyphenols of Fruits. In Nutritional Antioxidant Therapies: Treatments and Perspectives; Springer International Publishing: Cham, Germany, 2017; pp. 447-466. ISBN 9783319676258.

17. Guaadaoui, A.; Benaicha, S.; Elmajdoub, N.; Bellaoui, M.; Hamal, A. What is a bioactive compound? A combined definition for a preliminary consensus. Int. J. Food Sci. Nutr. 2014, 3, 174-179. [CrossRef]

18. Campos-Vega, R.; Oomah, B.D. Chemistry and classification of phytochemicals. In Handbook of Plant Food Phytochemicals; John Wiley \& Sons Ltd.: Oxford, UK, 2013; pp. 5-48. ISBN 9781444338102.

19. Ganesan, K.; Xu, B. Anti-diabetic effects and mechanisms of dietary polysaccharides. Molecules 2019, 24, 2556. [CrossRef] [PubMed]

20. Cao, H.; Ou, J.; Chen, L.; Zhang, Y.; Szkudelski, T.; Delmas, D.; Daglia, M.; Xiao, J. Dietary polyphenols and type 2 diabetes: Human Study and Clinical Trial. Crit. Rev. Food Sci. Nutr. 2019, 59, 3371-3379. [CrossRef] [PubMed] 
21. Renganathan, S.; Srivastava, A.; Pillai, R.G. Dhanwantaram kashayam, an Ayurvedic polyherbal formulation, reduces oxidative radicals and reverts lipids profile towards normal in diabetic rats. Biochem. Biophys. Rep. 2020, 22. [CrossRef]

22. Gharib, E.; Kouhsari, S.M. Study of the antidiabetic activity of Punica granatum L. Fruits aqueous extract on the alloxan-diabetic wistar rats. Iran. J. Pharm. Res. 2019, 18, 358-368. [CrossRef]

23. Sun, Y.; Yang, J.; Liu, W.; Yao, G.; Xu, F.; Hayashi, T.; Onodera, S.; Ikejima, T. Attenuating effect of silibinin on palmitic acid-induced apoptosis and mitochondrial dysfunction in pancreatic $\beta$-cells is mediated by estrogen receptor alpha. Mol. Cell. Biochem. 2019, 460, 81-92. [CrossRef]

24. Liu, I.-M.; Tzeng, T.-F.; Liou, S.-S.; Lan, T.-W. Myricetin, a naturally occurring flavonol, ameliorates insulin resistance induced by a high-fructose diet in rats. Life Sci. 2007, 81, 1479-1488. [CrossRef] [PubMed]

25. Samadder, A.; Chakraborty, D.; De, A.; Bhattacharyya, S.S.; Bhadra, K.; Khuda-Bukhsh, A.R. Possible signaling cascades involved in attenuation of alloxan-induced oxidative stress and hyperglycemia in mice by ethanolic extract of Syzygium jambolanum: Drug-DNA interaction with calf thymus DNA as target. Eur. J. Pharm. Sci. 2011, 44, 207-217. [CrossRef] [PubMed]

26. Johnson, M.H.; Lucius, A.; Meyer, T.; Gonzalez De Mejia, E. Cultivar evaluation and effect of fermentation on antioxidant capacity and in vitro inhibition of $\alpha$-amylase and $\alpha$-glucosidase by highbush blueberry (vaccinium corombosum). J. Agric. Food Chem. 2011, 59, 8923-8930. [CrossRef] [PubMed]

27. Grussu, D.; Stewart, D.; McDougall, G.J. Berry polyphenols inhibit $\alpha$-amylase in vitro: Identifying active components in rowanberry and raspberry. J. Agric. Food Chem. 2011, 59, 2324-2331. [CrossRef]

28. Liu, T.; Song, L.; Wang, H.; Huang, D. A high-throughput assay for quantification of starch hydrolase inhibition based on turbidity measurement. J. Agric. Food Chem. 2011, 59, 9756-9762. [CrossRef] [PubMed]

29. Krajka-Kuźniak, V.; Paluszczak, J.; Szaefer, H.; Baer-Dubowska, W. The activation of the Nrf2/ARE pathway in HepG2 hepatoma cells by phytochemicals and subsequent modulation of phase II and antioxidant enzyme expression. J. Physiol. Biochem. 2015, 71, 227-238. [CrossRef]

30. Muraoka, K.; Shimizu, K.; Sun, X.; Tani, T.; Izumi, R.; Miwa, K.; Yamamoto, K. Flavonoids exert diverse inhibitory effects on the activation of NF-KB. Transplant. Proc. 2002, 34, 1335-1340. [CrossRef]

31. Moon, S.K.; Cho, G.O.; Jung, S.Y.; Gal, S.W.; Kwon, T.K.; Lee, Y.C.; Madamanchi, N.R.; Kim, C.H. Quercetin exerts multiple inhibitory effects on vascular smooth muscle cells: Role of ERK1/2, cell-cycle regulation, and matrix metalloproteinase-9. Biochem. Biophys. Res. Commun. 2003, 301, 1069-1078. [CrossRef]

32. Forni, C.; Facchiano, F.; Bartoli, M.; Pieretti, S.; Facchiano, A.; D'Arcangelo, D.; Norelli, S.; Valle, G.; Nisini, R.; Beninati, S.; et al. Beneficial Role of Phytochemicals on Oxidative Stress and Age-Related Diseases. Biomed Res. Int. 2019, 2019, 1-16. [CrossRef] [PubMed]

33. Zakłos-Szyda, M.; Kowalska-Baron, A.; Pietrzyk, N.; Drzazga, A.; Podsędek, A. Evaluation of viburnum opulus 1. Fruit phenolics cytoprotective potential on insulinoma min6 cells relevant for diabetes mellitus and obesity. Antioxidants 2020, 9, 433. [CrossRef]

34. Liu, L.; Liang, C.; Mei, P.; Zhu, H.; Hou, M.; Yu, C.; Song, Z.; Bao, Y.; Huang, Y.; Yi, J.; et al. Dracorhodin perchlorate protects pancreatic $\beta$-cells against glucotoxicity-or lipotoxicity-induced dysfunction and apoptosis in vitro and in vivo. FEBS J. 2019, 286, 3718-3736. [CrossRef] [PubMed]

35. Kish-Trier, E.; Schwarz, E.L.; Pasquali, M.; Yuzyuk, T. Quantitation of total fatty acids in plasma and serum by GC-NCI-MS. Clin. Mass Spectrom. 2016, 2, 11-17. [CrossRef]

36. Sergeant, S.; Ruczinski, I.; Ivester, P.; Lee, T.C.; Morgan, T.M.; Nicklas, B.J.; Mathias, R.A.; Chilton, F.H. Impact of methods used to express levels of circulating fatty acids on the degree and direction of associations with blood lipids in humans. Br. J. Nutr. 2016, 115, 251-261. [CrossRef] [PubMed]

37. de Oliveira, C.; Khatua, B.; Noel, P.; Kostenko, S.; Bag, A.; Balakrishnan, B.; Patel, K.S.; Guerra, A.A.; Martinez, M.N.; Trivedi, S.; et al. Pancreatic triglyceride lipase mediates lipotoxic systemic inflammation. J. Clin. Investig. 2020, 130, $1931-1947$. [CrossRef] [PubMed]

38. Navina, S.; Acharya, C.; DeLany, J.P.; Orlichenko, L.S.; Baty, C.J.; Shiva, S.S.; Durgampudi, C.; Karlsson, J.M.; Lee, K.; Bae, K.T.; et al. Lipotoxicity causes multisystem organ failure and exacerbates acute pancreatitis in obesity. Sci. Transl. Med. 2011, 3, 107ra110. [CrossRef]

39. Paye, F.; Presset, O.; Chariot, J.; Molas, G.; Rozé, C. Role of nonesterified fatty acids in necrotizing pancreatitis: An in vivo experimental study in rats. Pancreas 2001, 23, 341-348. [CrossRef]

40. Christeff, N.; Homo-Delarche, F.; Thobie, N.; Durant, S.; Dardenne, M.; Nunez, E.A. Free fatty acid profiles in the non-obese diabetic (NOD) mouse: Basal serum levels and effects of endocrine manipulation. Prostaglandins Leukot. Essent. Fat. Acids 1994, 51, 125-131. [CrossRef]

41. Shimabukuro, M.; Higa, M.; Zhou, Y.T.; Wang, M.Y.; Newgard, C.B.; Unger, R.H. Lipoapoptosis in beta-cells of obese prediabetic $\mathrm{fa} /$ fa rats. Role of serine palmitoyltransferase overexpression. J. Biol. Chem. 1998, 273, 32487-32490. [CrossRef] [PubMed]

42. Wehinger, S.; Ortiz, R.; Díaz, M.I.; Aguirre, A.; Valenzuela, M.; Llanos, P.; Mc Master, C.; Leyton, L.; Quest, A.F.G. Phosphorylation of caveolin-1 on tyrosine-14 induced by ROS enhances palmitate-induced death of beta-pancreatic cells. Biochim. Biophys. Acta Mol. Basis Dis. 2015, 1852, 693-708. [CrossRef]

43. Mir, S.U.R.; George, N.M.; Zahoor, L.; Harms, R.; Guinn, Z.; Sarvetnick, N.E. Inhibition of autophagic turnover in $\beta$-cells by fatty acids and glucose leads to apoptotic cell death. J. Biol. Chem. 2015, 290, 6071-6085. [CrossRef] [PubMed] 
44. Kim, M.; Lee, J.S.; Oh, J.E.; Nan, J.; Lee, H.; Jung, H.S.; Chung, S.S.; Park, K.S. SIRT3 overexpression attenuates palmitate-induced pancreatic $\beta$-cell dysfunction. PLoS ONE 2015, 10, e0124744. [CrossRef] [PubMed]

45. Lameloise, N.; Muzzin, P.; Prentki, M.; Assimacopoulos-Jeannet, F. Uncoupling protein 2: A possible link between fatty acid excess and impaired glucose-induced insulin secretion? Diabetes 2001, 50, 803-809. [CrossRef] [PubMed]

46. Rachek, L.I.; Thornley, N.P.; Grishko, V.I.; LeDoux, S.P.; Wilson, G.L. Protection of INS-1 cells from free fatty acid-induced apoptosis by targeting hOGG1 to mitochondria. Diabetes 2006, 55, 1022-1028. [CrossRef] [PubMed]

47. Hu, H.Q.; Qiao, J.T.; Liu, F.Q.; Wang, J.B.; Sha, S.; He, Q.; Cui, C.; Song, J.; Zang, N.; Wang, L.S.; et al. The STING-IRF3 pathway is involved in lipotoxic injury of pancreatic $\beta$ cells in type 2 diabetes. Mol. Cell. Endocrinol. 2020, 110890. [CrossRef] [PubMed]

48. Cripps, M.J.; Bagnati, M.; Jones, T.A.; Ogunkolade, B.W.; Sayers, S.R.; Caton, P.W.; Hanna, K.; Billacura, M.P.; Fair, K.; Nelson, C.; et al. Identification of a subset of trace amine-associated receptors and ligands as potential modulators of insulin secretion. Biochem. Pharmacol. 2020, 171, 113685. [CrossRef]

49. Zhang, Q.; Cui, Q.; Hou, Y.; Wang, H.; Xu, Y.; Pi, J. The impairment of glucose-stimulated insulin secretion in pancreatic $\beta$-cells caused by prolonged glucotoxicity and lipotoxicity is associated with elevated adaptive antioxidant response. Food Chem. Toxicol. 2017, 100, 161-167. [CrossRef]

50. Qureshi, F.M.; Dejene, E.A.; Corbin, K.L.; Nunemaker, C.S. Stress-induced dissociations between intracellular calcium signaling and insulin secretion in pancreatic islets. Cell Calcium 2015, 57, 366-375. [CrossRef]

51. Alsabeeh, N.; Chausse, B.; Kakimoto, P.A.; Kowaltowski, A.J.; Shirihai, O. Cell culture models of fatty acid overload: Problems and solutions. Biochim. Biophys. Acta Mol. Cell Biol. Lipids 2018, 1863, 143-151. [CrossRef]

52. Timm, M.; Saaby, L.; Moesby, L.; Hansen, E.W. Considerations regarding use of solvents in in vitro cell based assays. Cytotechnology 2013, 65, 887-894. [CrossRef] [PubMed]

53. Roche, M.; Rondeau, P.; Singh, N.R.; Tarnus, E.; Bourdon, E. The antioxidant properties of serum albumin. FEBS Lett. 2008, 582, 1783-1787. [CrossRef] [PubMed]

54. Huang, K.T.; Chen, Y.H.; Walker, A.M. Inaccuracies in MTS assays: Major distorting effects of medium, serum albumin, and fatty acids. Biotechniques 2004, 37, 406-412. [CrossRef]

55. Li, F.; Munsey, T.S.; Sivaprasadarao, A. TRPM2-mediated rise in mitochondrial Zn 2+ promotes palmitate-induced mitochondrial fission and pancreatic $\beta$-cell death in rodents. Cell Death Differ. 2017, 24, 1999-2012. [CrossRef] [PubMed]

56. Ježek, J.; Dlasková, A.; Zelenka, J.; Jabůrek, M.; Ježek, P. H2O2-activated mitochondrial phospholipase iPLA2 $\gamma$ prevents lipotoxic oxidative stress in synergy with UCP2, amplifies signaling via G-protein-coupled receptor GPR40, and regulates insulin secretion in pancreatic $\beta$-cells. Antioxidants Redox Signal. 2015, 23, 958-972. [CrossRef] [PubMed]

57. Cnop, M.; Hannaert, J.C.; Hoorens, A.; Eizirik, D.L.; Pipeleers, D.G. Inverse Relationship between Cytotoxicity of Free Fatty Acids in Pancreatic Islet Cells and Cellular Triglyceride Accumulation. Diabetes 2001, 50, 1771-1777. [CrossRef] [PubMed]

58. Oliveira, A.F.; Cunha, D.A.; Ladriere, L.; Igoillo-Esteve, M.; Bugliani, M.; Marchetti, P.; Cnop, M. In vitro use of free fatty acids bound to albumin: A comparison of protocols. Biotechniques 2015, 58, 228-233. [CrossRef] [PubMed]

59. Saitoh, Y.; Hongwei, W.; Ueno, H.; Mizuta, M.; Nakazato, M. Candesartan attenuates fatty acid-induced oxidative stress and NAD $(\mathrm{P}) \mathrm{H}$ oxidase activity in pancreatic $\beta$-cells. Diabetes Res. Clin. Pract. 2010, 90, 54-59. [CrossRef]

60. Hansen, J.B.; Dos Santos, L.R.B.; Liu, Y.; Prentice, K.J.; Teudt, F.; Tonnesen, M.; Jonas, J.C.; Wheeler, M.B.; Mandrup-Poulsen, T. Glucolipotoxic conditions induce $\beta$-cell iron import, cytosolic ROS formation and apoptosis. J. Mol. Endocrinol. 2018, 61, 69-77. [CrossRef]

61. Sobczak, A.I.S.; A. Blindauer, C.; J. Stewart, A. Changes in Plasma Free Fatty Acids Associated with Type-2 Diabetes. Nutrients 2019, 11, 2022. [CrossRef]

62. Cnop, M.; Welsh, N.; Jonas, J.C.; Jörns, A.; Lenzen, S.; Eizirik, D.L. Mechanisms of pancreatic $\beta$-cell death in type 1 and type 2 diabetes: Many differences, few similarities. Diabetes 2005, 54 (Suppl. 2), 97-107. [CrossRef]

63. Wu, P.; Yang, L.; Shen, X. The relationship between GPR40 and lipotoxicity of the pancreatic $\beta$-cells as well as the effect of pioglitazone. Biochem. Biophys. Res. Commun. 2010, 403, 36-39. [CrossRef]

64. Plötz, T.; von Hanstein, A.S.; Krümmel, B.; Laporte, A.; Mehmeti, I.; Lenzen, S. Structure-toxicity relationships of saturated and unsaturated free fatty acids for elucidating the lipotoxic effects in human EndoC- $\beta \mathrm{H} 1$ beta-cells. Biochim. Biophys. Acta Mol. Basis Dis. 2019, 1865, 165525. [CrossRef] [PubMed]

65. Clarke, D.C.; Miskovic, D.; Han, X.-X.; Calles-Escandon, J.; Glatz, J.F.C.; Luiken, J.J.F.P.; Heikkila, J.J.; Bonen, A. Overexpression of membrane-associated fatty acid binding protein (FABPpm) in vivo increases fatty acid sarcolemmal transport and metabolism. Physiol. Genomics 2004, 17, 31-37. [CrossRef] [PubMed]

66. Ly, L.D.; Xu, S.; Choi, S.K.; Ha, C.M.; Thoudam, T.; Cha, S.K.; Wiederkehr, A.; Wollheim, C.B.; Lee, I.K.; Park, K.S. Oxidative stress and calcium dysregulation by palmitate in type 2 diabetes. Exp. Mol. Med. 2017, 49, e291-12. [CrossRef]

67. Pepino, M.Y.; Kuda, O.; Samovski, D.; Abumrad, N.A. Structure-function of CD36 and importance of fatty acid signal transduction in fat metabolism. Annu. Rev. Nutr. 2014, 34, 281-303. [CrossRef] [PubMed]

68. Okamura, D.M.; Pennathur, S.; Pasichnyk, K.; López-Guisa, J.M.; Collins, S.; Febbraio, M.; Heinecke, J.; Eddy, A.A. CD36 regulates oxidative stress and inflammation in hypercholesterolemic CKD. J. Am. Soc. Nephrol. 2009, 20, 495-505. [CrossRef]

69. Kim, Y.W.; Moon, J.S.; Seo, Y.J.; Park, S.Y.; Kim, J.Y.; Yoon, J.S.; Lee, I.K.; Lee, H.W.; Won, K.C. Inhibition of fatty acid translocase cluster determinant 36 (CD36), stimulated by hyperglycemia, prevents glucotoxicity in INS-1 cells. Biochem. Biophys. Res. Commun. 2012, 420, 462-466. [CrossRef] 
70. Kristinsson, H.; Sargsyan, E.; Manell, H.; Smith, D.M.; Göpel, S.O.; Bergsten, P. Basal hypersecretion of glucagon and insulin from palmitate-exposed human islets depends on FFAR1 but not decreased somatostatin secretion. Sci. Rep. 2017, 7, 4657. [CrossRef] [PubMed]

71. Zhao, Y.; Wang, L.; Qiu, J.; Zha, D.; Sun, Q.; Chen, C. Linoleic Acid Stimulates [Ca2+]i Increase in Rat Pancreatic Beta-Cells through Both Membrane Receptor- and Intracellular Metabolite-Mediated Pathways. PLoS ONE 2013, 8, e60255. [CrossRef]

72. Chen, Y.; Ren, Q.; Zhou, Z.; Deng, L.; Hu, L.; Zhang, L.; Li, Z. HWL-088, a new potent free fatty acid receptor 1 (FFAR1) agonist, improves glucolipid metabolism and acts additively with metformin in ob/ob diabetic mice. Br. J. Pharmacol. 2020, 177, $2286-2302$. [CrossRef]

73. Ly, L.D.; Da Ly, D.; Nguyen, N.T.; Kim, J.H.; Yoo, H.; Chung, J.; Lee, M.S.; Cha, S.K.; Park, K.S. Mitochondrial Ca2+ Uptake Relieves Palmitate-Induced Cytosolic Ca2+ Overload in MIN6 Cells. Mol. Cells 2020, 43, 66-75. [CrossRef]

74. Biden, T.J.; Boslem, E.; Chu, K.Y.; Sue, N. Lipotoxic endoplasmic reticulum stress, $\beta$ cell failure, and type 2 diabetes mellitus. Trends Endocrinol. Metab. 2014, 25, 389-398. [CrossRef]

75. Schreurs, M.; Kuipers, F.; van der Leij, F.R. Regulatory enzymes of mitochondrial $\beta$-oxidation as targets for treatment of the metabolic syndrome. Obes. Rev. 2010, 11, 380-388. [CrossRef] [PubMed]

76. Wan, J.; Jiang, L.; Lü, Q.; Ke, L.; Li, X.; Tong, N. Activation of PPAR $\delta$ up-regulates fatty acid oxidation and energy uncoupling genes of mitochondria and reduces palmitate-induced apoptosis in pancreatic $\beta$-cells. Biochem. Biophys. Res. Commun. 2010, 391, 1567-1572. [CrossRef] [PubMed]

77. Talley, J.T.; Mohiuddin, S.S. Biochemistry, Fatty Acid Oxidation; StatPearls Publishing: Treasure Island, FL, USA, 2020.

78. Maris, M.; Robert, S.; Waelkens, E.; Derua, R.; Hernangomez, M.H.; D’Hertog, W.; Cnop, M.; Mathieu, C.; Overbergh, L. Role of the saturated nonesterified fatty acid palmitate in beta cell dysfunction. J. Proteome Res. 2013, 12, 347-362. [CrossRef]

79. Lee, J.H.; Jung, I.R.; Choi, S.E.; Lee, S.M.; Lee, S.J.; Han, S.J.; Kim, H.J.; Kim, D.J.; Lee, K.W.; Kang, Y. Toxicity generated through inhibition of pyruvate carboxylase and carnitine palmitoyl transferase- 1 is similar to high glucose/palmitate-induced glucolipotoxicity in INS-1 beta cells. Mol. Cell. Endocrinol. 2014, 383, 48-59. [CrossRef] [PubMed]

80. Abdul-Ghani, M.A.; Muller, F.L.; Liu, Y.; Chavez, A.O.; Balas, B.; Zuo, P.; Chang, Z.; Tripathy, D.; Jani, R.; Molina-Carrion, M.; et al. Deleterious action of FA metabolites on ATP synthesis: Possible link between lipotoxicity, mitochondrial dysfunction, and insulin resistance. Am. J. Physiol. Endocrinol. Metab. 2008, 295, 678-685. [CrossRef]

81. Lu, H.; Koshkin, V.; Allister, E.M.; Gyulkhandanyan, A.V.; Wheeler, M.B. Molecular and metabolic evidence for mitochondrial defects associated with $\beta$-cell dysfunction in a mouse model of type 2 diabetes. Diabetes 2010, 59, 448-459. [CrossRef] [PubMed]

82. MacDonald, M.J.; Longacre, M.J.; Langberg, E.C.; Tibell, A.; Kendrick, M.A.; Fukao, T.; Ostenson, C.G. Decreased levels of metabolic enzymes in pancreatic islets of patients with type 2 diabetes. Diabetologia 2009, 52, 1087-1091. [CrossRef] [PubMed]

83. Nagaraju, R.; Rajini, P.S. Adaptive response of rat pancreatic $\beta$-cells to insulin resistance induced by monocrotophos: Biochemical evidence. Pestic. Biochem. Physiol. 2016, 134, 39-48. [CrossRef]

84. Cunha, D.A.; Igoillo-Esteve, M.; Gurzov, E.N.; Germano, C.M.; Naamane, N.; Marhfour, I.; Fukaya, M.; Vanderwinden, J.M.; Gysemans, C.; Mathieu, C.; et al. Death protein 5 and p53-upregulated modulator of apoptosis mediate the endoplasmic reticulum stress-mitochondrial dialog triggering lipotoxic rodent and human $\beta$-cell apoptosis. Diabetes 2012, 61, 2763-2775. [CrossRef] [PubMed]

85. Boucher, A.; Lu, D.; Burgess, S.C.; Telemaque-Potts, S.; Jensen, M.V.; Mulder, H.; Wang, M.Y.; Unger, R.H.; Sherry, A.D.; Newgard, C.B. Biochemical mechanism of lipid-induced impairment of glucose-stimulated insulin secretion and reversal with a malate analogue. J. Biol. Chem. 2004, 279, 27263-27271. [CrossRef]

86. Carlessi, R.; Rowlands, J.; Ellison, G.; Helena de Oliveira Alves, H.; Newsholme, P.; Mamotte, C. Glutamine deprivation induces metabolic adaptations associated with beta cell dysfunction and exacerbate lipotoxicity. Mol. Cell. Endocrinol. 2019, $491,110433$. [CrossRef] [PubMed]

87. Yang, C.; Ko, B.; Hensley, C.T.; Jiang, L.; Wasti, A.T.; Kim, J.; Sudderth, J.; Calvaruso, M.A.; Lumata, L.; Mitsche, M.; et al. Glutamine oxidation maintains the TCA cycle and cell survival during impaired mitochondrial pyruvate transport. Mol. Cell 2014, 56, 414-424. [CrossRef]

88. Roberts, L.D.; Koulman, A.; Griffin, J.L. Towards metabolic biomarkers of insulin resistance and type 2 diabetes: Progress from the metabolome. Lancet Diabetes Endocrinol. 2014, 2, 65-75. [CrossRef]

89. Stančáková, A.; Civelek, M.; Saleem, N.K.; Soininen, P.; Kangas, A.J.; Cederberg, H.; Paananen, J.; Pihlajamäki, J.; Bonnycastle, L.L.; Morken, M.A.; et al. Hyperglycemia and a common variant of GCKR are associated with the levels of eight amino acids in 9369 finnish men. Diabetes 2012, 61, 1895-1902. [CrossRef]

90. Van Loon, L.J.C.; Kruijshoop, M.; Menheere, P.P.C.A.; Wagenmakers, A.J.M.; Saris, W.H.M.; Keizer, H.A. Amino acid ingestion strongly enhances insulin secretion in patients with long-term type 2 diabetes. Diabetes Care 2003, 26, 625-630. [CrossRef]

91. Zhou, Y.; Chung, A.C.K.; Fan, R.; Lee, H.M.; Xu, G.; Tomlinson, B.; Chan, J.C.N.; Kong, A.P.S. Sirt3 Deficiency Increased the Vulnerability of Pancreatic Beta Cells to Oxidative Stress-Induced Dysfunction. Antioxidants Redox Signal. 2017, 27, 962-976. [CrossRef]

92. Tran, K.; Li, Y.; Duan, H.; Arora, D.; Lim, H.Y.; Wang, W. Identification of small molecules that protect pancreatic $\beta$ cells against endoplasmic reticulum stress-induced cell death. ACS Chem. Biol. 2014, 9, 2796-2806. [CrossRef]

93. Zhou, Y.P.; Berggren, P.O.; Grill, V. A fatty acid-induced decrease in pyruvate dehydrogenase activity is an important determinant of $\beta$-cell dysfunction in the obese diabetic $\mathrm{db} / \mathrm{db}$ mouse. Diabetes 1996, 45, 580-586. [CrossRef] 
94. Rodríguez-Manzaneque, M.T.; Tamarit, J.; Bellí, G.; Ros, J.; Herrero, E. Grx5 is a mitochondrial glutaredoxin required for the activity of iron/sulfur enzymes. Mol. Biol. Cell 2002, 13, 1109-1121. [CrossRef] [PubMed]

95. Petry, S.F.; Sun, L.M.; Knapp, A.; Reinl, S.; Linn, T. Distinct shift in beta-cell glutaredoxin 5 expression is mediated by hypoxia and lipotoxicity both in vivo and in vitro. Front. Endocrinol. 2018, 9, 1-11. [CrossRef]

96. Stehling, O.; Wilbrecht, C.; Lill, R. Mitochondrial iron-sulfur protein biogenesis and human disease. Biochimie 2014, 100, 61-77. [CrossRef] [PubMed]

97. Braymer, J.J.; Lill, R. Iron-sulfur cluster biogenesis and trafficking in mitochondria. J. Biol. Chem. 2017, 292, 12754-12763. [CrossRef]

98. Flemming, D.; Schlitt, A.; Spehr, V.; Bischof, T.; Friedrich, T. Iron-Sulfur Cluster N2 of the Escherichia coli NADH:Ubiquinone Oxidoreductase (Complex I) Is Located on Subunit NuoB. J. Biol. Chem. 2003, 278, 47602-47609. [CrossRef] [PubMed]

99. Albracht, S.P.J. The prosthetic groups in succinate dehydrogenase Number and stoichiometry. BBA Enzymol. 1980, 612, 11-28. [CrossRef]

100. Ding, H.; Robertson, D.E.; Daldal, F.; Dutton, P.L. Cytochrome bc1 complex [2Fe-2S] cluster and its interaction with ubiquinone and ubihydroquinone at the Qo site: A double-occupancy Qo site model. Biochemistry 1992, 31, 3144-3158. [CrossRef] [PubMed]

101. Khoroshilova, N.; Popescu, C.; Münck, E.; Beinert, H.; Kiley, P.J. Iron-sulfur cluster disassembly in the FNR protein of Escherichia coli by O2: [4Fe-4S] to [2Fe-2S] conversion with loss of biological activity. Proc. Natl. Acad. Sci. USA 1997, 94, 6087-6092. [CrossRef]

102. Fuss, J.O.; Tsai, C.L.; Ishida, J.P.; Tainer, J.A. Emerging critical roles of Fe-S clusters in DNA replication and repair. Biochim. Biophys. Acta Mol. Cell Res. 2015, 1853, 1253-1271. [CrossRef]

103. Rosenbohm, A.; Süssmuth, S.D.; Kassubek, J.; Müller, H.-P.; Pontes, C.; Abicht, A.; Bulst, S.; Ludolph, A.C.; Pinkhardt, E. Novel ETFDH mutation and imaging findings in an adult with glutaric aciduria type II. Muscle Nerve 2014, 49, 446-450. [CrossRef]

104. Robbins, A.H.; Stout, C.D. Structure of activated aconitase: Formation of the [4Fe-4S] cluster in the crystal. Proc. Natl. Acad. Sci. USA 1989, 86, 3639-3643. [CrossRef]

105. Rouault, T.A. The role of iron regulatory proteins in mammalian iron homeostasis and disease. Nat. Chem. Biol. 2006, 2, 406-414. [CrossRef] [PubMed]

106. Camaschella, C.; Campanella, A.; De Falco, L.; Boschetto, L.; Merlini, R.; Silvestri, L.; Levi, S.; Iolascon, A. The human counterpart of zebrafish shiraz shows sideroblastic-like microcytic anemia and iron overload. Blood 2007, 110, 1353-1358. [CrossRef]

107. Dixon, S.J.; Lemberg, K.M.; Lamprecht, M.R.; Skouta, R.; Zaitsev, E.M.; Gleason, C.E.; Patel, D.N.; Bauer, A.J.; Cantley, A.M.; Yang, W.S.; et al. Ferroptosis: An iron-dependent form of nonapoptotic cell death. Cell 2012, 149, 1060-1072. [CrossRef]

108. Koulajian, K.; Ivovic, A.; Ye, K.; Desai, T.; Shah, A.; George Fantus, I.; Ran, Q.; Giacca, A. Overexpression of glutathione peroxidase 4 prevents $\beta$-cell dysfunction induced by prolonged elevation of lipids in vivo. Am. J. Physiol. Endocrinol. Metab. 2013, 305, E254-62. [CrossRef]

109. Santangelo, C.; Matarrese, P.; Masella, R.; Di Carlo, M.C.; Di Lillo, A.; Scazzocchio, B.; Vecci, E.; Malorni, W.; Perfetti, R.; Anastasi, E. Hepatocyte growth factor protects rat RINm5F cell line against free fatty acid-induced apoptosis by counteracting oxidative stress. J. Mol. Endocrinol. 2007, 38, 147-158. [CrossRef] [PubMed]

110. Xu, P.; Qiao, K.; Stephanopoulos, G. Engineering oxidative stress defense pathways to build a robust lipid production platform in Yarrowia lipolytica. Biotechnol. Bioeng. 2017, 114, 1521-1530. [CrossRef] [PubMed]

111. Baker, P.R.; Friederich, M.W.; Swanson, M.A.; Shaikh, T.; Bhattacharya, K.; Scharer, G.H.; Aicher, J.; Creadon-Swindell, G.; Geiger, E.; Maclean, K.N.; et al. Variant non ketotic hyperglycinemia is caused by mutations in LIAS, BOLA3 and the novel gene GLRX5. Brain 2014, 137, 366-379. [CrossRef] [PubMed]

112. Liu, G.; Guo, S.; Anderson, G.J.; Camaschella, C.; Han, B.; Nie, G. Heterozygous missense mutations in the GLRX5 gene cause sideroblastic anemia in a Chinese patient. Blood 2014, 124, 2750-2751. [CrossRef]

113. Chiu, C.F.; Lin, J.L.; Lin, J.J.; Tseng, M.H.; Lo, F.S.; Chiang, M.C. Nonketotic Hyperglycinemia of Infants in Taiwan. Pediatr. Neonatol. 2016, 57, 420-426. [CrossRef]

114. Daher, R.; Mansouri, A.; Martelli, A.; Bayart, S.; Manceau, H.; Callebaut, I.; Moulouel, B.; Gouya, L.; Puy, H.; Kannengiesser, C.; et al. GLRX5 mutations impair heme biosynthetic enzymes ALA synthase 2 and ferrochelatase in Human congenital sideroblastic anemia. Mol. Genet. Metab. 2019, 128, 342-351. [CrossRef]

115. Elsner, M.; Gehrmann, W.; Lenzen, S. Peroxisome-generated hydrogen peroxide as important mediator of lipotoxicity in insulin-producing cells. Diabetes 2011, 60, 200-208. [CrossRef]

116. Koshkin, V.; Wang, X.; Scherer, P.E.; Chan, C.B.; Wheeler, M.B. Mitochondrial functional state in clonal pancreatic $\beta$-cells exposed to free fatty acids. J. Biol. Chem. 2003, 278, 19709-19715. [CrossRef]

117. Pujol, J.B.; Christinat, N.; Ratinaud, Y.; Savoia, C.; Mitchell, S.E.; Dioum, E.H.M. Coordination of GPR40 and ketogenesis signaling by medium chain fatty acids regulates beta cell function. Nutrients 2018, 10, 473. [CrossRef] [PubMed]

118. Quehenberger, O.; Armando, A.M.; Brown, A.H.; Milne, S.B.; Myers, D.S.; Merrill, A.H.; Bandyopadhyay, S.; Jones, K.N.; Kelly, S.; Shaner, R.L.; et al. Lipidomics reveals a remarkable diversity of lipids in human plasma1. J. Lipid Res. 2010, 51, $3299-3305$. [CrossRef] [PubMed]

119. Osumi, T.; Hashimoto, T. Acyl-CoA oxidase of rat liver: A new enzyme for fatty acid oxidation. Biochem. Biophys. Res. Commun. 1978, 83, 479-485. [CrossRef] 
120. Gehrmann, W.; Elsner, M.; Lenzen, S. Role of metabolically generated reactive oxygen species for lipotoxicity in pancreatic $\beta$-cells. Diabetes. Obes. Metab. 2010, 12, 149-158. [CrossRef]

121. Laporte, A.; Lortz, S.; Schaal, C.; Lenzen, S.; Elsner, M. Hydrogen peroxide permeability of cellular membranes in insulinproducing cells. Biochim. Biophys. Acta Biomembr. 2020, 1862, 183096. [CrossRef]

122. Lenzen, S.; Drinkgern, J.; Tiedge, M. Low antioxidant enzyme gene expression in pancreatic islets compared with various other mouse tissues. Free Radic. Biol. Med. 1996, 20, 463-466. [CrossRef]

123. Stancill, J.S.; Broniowska, K.A.; Oleson, B.J.; Naatz, A.; Corbett, J.A. Pancreatic $\beta$-cells detoxify H2O2 through the peroxiredoxin/thioredoxin antioxidant system. J. Biol. Chem. 2019, 294, 4843-4853. [CrossRef]

124. Klingenberg, M.; Winkler, E. The reconstituted isolated uncoupling protein is a membrane potential driven $\mathrm{H}+$ translocator. EMBO J. 1985, 4, 3087-3092. [CrossRef] [PubMed]

125. Chan, C.B.; MacDonald, P.E.; Saleh, M.C.; Johns, D.C.; Marbàn, E.; Wheeler, M.B. Overexpression of uncoupling protein 2 inhibits glucose-stimulated insulin secretion from rat islets. Diabetes 1999, 48, 1482-1486. [CrossRef] [PubMed]

126. Fedorenko, A.; Lishko, P.V.; Kirichok, Y. Mechanism of fatty-acid-dependent UCP1 uncoupling in brown fat mitochondria. Cell 2012, 151, 400-413. [CrossRef] [PubMed]

127. Solmonson, A.; Mills, E.M. Uncoupling Proteins and the Molecular Mechanisms of Thyroid Thermogenesis. Endocrinology 2016, 157, 455-462. [CrossRef] [PubMed]

128. Echtay, K.S.; Roussel, D.; St-Pierre, J.; Jekabsons, M.B.; Cadenas, S.; Stuart, J.A.; Harper, J.A.; Roebuck, S.J.; Morrison, A.; Pickering, S.; et al. Superoxide activates mitochondrial uncoupling proteins. Nature 2002, 415, 96-99. [CrossRef]

129. Hu, M.; Lin, H.; Yang, L.; Cheng, Y.; Zhang, H. Interleukin-22 restored mitochondrial damage and impaired glucose-stimulated insulin secretion through down-regulation of uncoupling protein-2 in INS-1 cells. J. Biochem. 2017, 161, 433-439. [CrossRef]

130. Birk, A.V.; Chao, W.M.; Bracken, C.; Warren, J.D.; Szeto, H.H. Targeting mitochondrial cardiolipin and the cytochrome c /cardiolipin complex to promote electron transport and optimize mitochondrial ATP synthesis. Br. J. Pharmacol. 2014, 171, 2017-2028. [CrossRef]

131. Li, Z.; Zhou, Z.; Huang, G.; Hu, F.; Xiang, Y.; He, L. Exendin-4 Protects Mitochondria from Reactive Oxygen Species Induced Apoptosis in Pancreatic Beta Cells. PLoS ONE 2013, 8, e76172. [CrossRef] [PubMed]

132. Gu, J.; Wei, Q.; Zheng, H.; Meng, X.; Zhang, J.; Wang, D. Exendin-4 Promotes Survival of Mouse Pancreatic $\beta$-Cell Line in Lipotoxic Conditions, through the Extracellular Signal-Related Kinase 1/2 Pathway. J. Diabetes Res. 2016, 2016, 1-8. [CrossRef] [PubMed]

133. Ciregia, F.; Giusti, L.; Ronci, M.; Bugliani, M.; Piga, I.; Pieroni, L.; Rossi, C.; Marchetti, P.; Urbani, A.; Lucacchini, A. Glucagon-like peptide 1 protects INS-1E mitochondria against palmitate-mediated beta-cell dysfunction: A proteomic study. Mol. Biosyst. 2015, 11, 1696-1707. [CrossRef] [PubMed]

134. Lee, K.M.; Seo, Y.J.; Kim, M.K.; Seo, H.A.; Jeong, J.Y.; Choi, H.S.; Lee, I.K.; Park, K. gyu Mediation of glucolipotoxicity in INS-1 rat insulinoma cells by small heterodimer partner interacting leucine zipper protein (SMILE). Biochem. Biophys. Res. Commun. 2012, 419, 768-773. [CrossRef]

135. Tyagi, S.; Gupta, P.; Saini, A.; Kaushal, C.; Sharma, S. The peroxisome proliferator-activated receptor: A family of nuclear receptors role in various diseases. J. Adv. Pharm. Technol. Res. 2011, 2, 236-240. [CrossRef]

136. Poitout, V. $\beta$-Cell Lipotoxicity: Burning Fat into Heat? Endocrinology 2004, 145, 3563-3565. [CrossRef] [PubMed]

137. Winzell, M.S.; Svensson, H.; Enerbäck, S.; Ravnskjaer, K.; Mandrup, S.; Esser, V.; Arner, P.; Alves-Guerra, M.C.; Miroux, B.; Sundler, F.; et al. Pancreatic $\beta$-cell lipotoxicity induced by overexpression of hormone-sensitive lipase. Diabetes 2003, 52, $2057-2065$. [CrossRef]

138. Tordjman, K.; Standley, K.N.; Bernal-Mizrachi, C.; Leone, T.C.; Coleman, T.; Kelly, D.P.; Semenkovich, C.F. PPAR $\alpha$ suppresses insulin secretion and induces UCP2 in insulinoma cells. J. Lipid Res. 2002, 43, 936-943. [CrossRef]

139. Higa, M.; Zhou, Y.T.; Ravazzola, M.; Baetens, D.; Orci, L.; Unger, R.H. Troglitazone prevents mitochondrial alterations, $\beta$ cell destruction, and diabetes in obese prediabetic rats. Proc. Natl. Acad. Sci. USA 1999, 96, 11513-11518. [CrossRef] [PubMed]

140. Joseph, J.W.; Koshkin, V.; Saleh, M.C.; Sivitz, W.I.; Zhang, C.Y.; Lowell, B.B.; Chan, C.B.; Wheeler, M.B. Free fatty acid-induced $\beta$-cell defects are dependent on uncoupling protein 2 expression. J. Biol. Chem. 2004, 279, 51049-51056. [CrossRef]

141. Yamashita, T.; Eto, K.; Okazaki, Y.; Yamashita, S.; Yamauchi, T.; Sekine, N.; Nagai, R.; Noda, M.; Kadowaki, T. Role of uncoupling protein-2 up-regulation and triglyceride accumulation in impaired glucose-stimulated insulin secretion in a $\beta$-cell lipotoxicity model overexpressing sterol regulatory element-binding protein-1c. Endocrinology 2004, 145, 3566-3577. [CrossRef] [PubMed]

142. Medvedev, A.V.; Robidoux, J.; Bai, X.; Cao, W.; Floering, L.M.; Daniel, K.W.; Collins, S. Regulation of the uncoupling protein-2 gene in INS-1 $\beta$-cells by oleic acid. J. Biol. Chem. 2002, 277, 42639-42644. [CrossRef] [PubMed]

143. Oberhauser, L.; Granziera, S.; Colom, A.; Goujon, A.; Lavallard, V.; Matile, S.; Roux, A.; Brun, T.; Maechler, P. Palmitate and oleate modify membrane fluidity and kinase activities of INS-1E $\beta$-cells alongside altered metabolism-secretion coupling. Biochim. Biophys. Acta Mol. Cell Res. 2020, 1867, 118619. [CrossRef]

144. Papa, S.; Guerrieri, F.; Zanotti, F.; Fiermonte, M.; Capozza, G.; Jirillo, E. The $\gamma$ subunit of F1 and the PVP protein of Fo (FoI) are components of the gate of the mitochondrial FoF1 H+-ATP synthase. FEBS Lett. 1990, 272, 117-120. [CrossRef]

145. Köhnke, R.; Mei, J.; Park, M.J.; York, D.A.; Erlanson-Albertsson, C. Fatty acids and glucose in high concentration down-regulates ATP synthase $\beta$-subunit protein expression in INS-1 cells. Nutr. Neurosci. 2007, 10, 273-278. [CrossRef] 
146. Ciregia, F.; Bugliani, M.; Ronci, M.; Giusti, L.; Boldrini, C.; Mazzoni, M.R.; Mossuto, S.; Grano, F.; Cnop, M.; Marselli, L.; et al. Palmitate-induced lipotoxicity alters acetylation of multiple proteins in clonal $\beta$ cells and human pancreatic islets. Sci. Rep. 2017, 7, 13445. [CrossRef] [PubMed]

147. Amo, T.; Sato, S.; Saiki, S.; Wolf, A.M.; Toyomizu, M.; Gautier, C.A.; Shen, J.; Ohta, S.; Hattori, N. Mitochondrial membrane potential decrease caused by loss of PINK1 is not due to proton leak, but to respiratory chain defects. Neurobiol. Dis. 2011, 41, 111-118. [CrossRef] [PubMed]

148. Grubelnik, V.; Markovič, R.; Lipovšek, S.; Leitinger, G.; Gosak, M.; Dolenšek, J.; Valladolid-Acebes, I.; Berggren, P.O.; Stožer, A.; Perc, M.; et al. Modelling of dysregulated glucagon secretion in type 2 diabetes by considering mitochondrial alterations in pancreatic $\alpha$-cells. R. Soc. Open Sci. 2020, 7, 191171. [CrossRef] [PubMed]

149. Grubelnik, V.; Zmazek, J.; Markovič, R.; Gosak, M.; Marhl, M. Modelling of energy-driven switch for glucagon and insulin secretion. J. Theor. Biol. 2020, 493, 110213. [CrossRef] [PubMed]

150. Köhnke, D.; Ludwig, B.; Kadenbach, B. A threshold membrane potential accounts for controversial effects of fatty acids on mitochondrial oxidative phosphorylation. FEBS Lett. 1993, 336, 90-94. [CrossRef]

151. Sargsyan, E.; Bergsten, P. Lipotoxicity is glucose-dependent in INS-1E cells but not in human islets and MIN6 cells. Lipids Health Dis. 2011, 10, 115. [CrossRef] [PubMed]

152. Nakata, M.; Shintani, N.; Hashimoto, H.; Baba, A.; Yada, T. Intra-islet PACAP protects pancreatic $\beta$-cells against glucotoxicity and lipotoxicity. J. Mol. Neurosci. 2010, 42, 404-410. [CrossRef]

153. Kato, T.; Shimano, H.; Yamamoto, T.; Ishikawa, M.; Kumadaki, S.; Matsuzaka, T.; Nakagawa, Y.; Yahagi, N.; Nakakuki, M.; Hasty, A.H.; et al. Palmitate impairs and eicosapentaenoate restores insulin secretion through regulation of SREBP-1c in pancreatic islets. Diabetes 2008, 57, 2382-2392. [CrossRef] [PubMed]

154. Hirota, N.; Otabe, S.; Nakayama, H.; Yuan, X.; Yamada, K. Sequential activation of caspases and synergistic $\beta$-cell cytotoxicity by palmitate and anti-Fas antibodies. Life Sci. 2006, 79, 1312-1316. [CrossRef]

155. Maedler, K.; Oberholzer, J.; Bucher, P.; Spinas, G.A.; Donath, M.Y. Monounsaturated fatty acids prevent the deleterious effects of palmitate and high glucose on human pancreatic $\beta$-cell turnover and function. Diabetes 2003, 52, 726-733. [CrossRef] [PubMed]

156. Briaud, I.; Harmon, J.S.; Kelpe, C.L.; Segu, V.B.G.; Poitout, V. Lipotoxicity of the pancreatic $\beta$-cell is associated with glucosedependent esterification of fatty acids into neutral lipids. Diabetes 2001, 50, 315-321. [CrossRef]

157. Frigerio, F.; Chaffard, G.; Berwaer, M.; Maechler, P. The antiepileptic drug topiramate preserves metabolism-secretion coupling in insulin secreting cells chronically exposed to the fatty acid oleate. Biochem. Pharmacol. 2006, 72, 965-973. [CrossRef] [PubMed]

158. Li, Z.; Zhou, Z.; Hu, L.; Deng, L.; Ren, Q.; Zhang, L. ZLY032, the first-in-class dual FFA1/PPAR $\delta$ agonist, improves glucolipid metabolism and alleviates hepatic fibrosis. Pharmacol. Res. 2020, 159, 105035. [CrossRef] [PubMed]

159. Dean, P.M. Ultrastructural morphometry of the pancreatic $\beta$-cell. Diabetologia 1973, 9, 115-119. [CrossRef]

160. Deeney, J.T.; Tornheim, K.; Korchak, H.M.; Prentki, M.; Corkey, B.E. Acyl-CoA esters modulate intracellular Ca2+ handling by permeabilized clonal pancreatic beta-cells. J. Biol. Chem. 1992, 267, 19840-19845. [CrossRef]

161. Fujitani, Y.; Ebato, C.; Uchida, T.; Kawamori, R.; Watada, H. $\beta$-cell autophagy: A novel mechanism regulating $\beta$-cell function and mass- Lessons from $\beta$-cell-specific Atg7-deficient mice. Islets 2009, 1, 151-153. [CrossRef] [PubMed]

162. Guo, T.; Liu, T.; Sun, Y.; Liu, X.; Xiong, R.; Li, H.; Li, Z.; Zhang, Z.; Tian, Z.; Tian, Y. Sonodynamic therapy inhibits palmitateinduced beta cell dysfunction via PINK1/Parkin-dependent mitophagy. Cell Death Dis. 2019, 10, 457. [CrossRef] [PubMed]

163. Petcherski, A.; Trudeau, K.M.; Wolf, D.M.; Segawa, M.; Lee, J.; Taddeo, E.P.; Deeney, J.T.; Liesa, M. Elamipretide Promotes Mitophagosome Formation and Prevents Its Reduction Induced by Nutrient Excess in INS1 $\beta$-cells. J. Mol. Biol. 2018, 430, 4823-4833. [CrossRef] [PubMed]

164. Assali, E.A.; Shlomo, D.; Zeng, J.; Taddeo, E.P.; Trudeau, K.M.; Erion, K.A.; Colby, A.H.; Grinstaff, M.W.; Liesa, M.; Las, G.; et al. Nanoparticle-mediated lysosomal reacidification restores mitochondrial turnover and function in $\beta$ cells under lipotoxicity. FASEB J. 2019, 33, 4154-4165. [CrossRef]

165. Peng, L.; Men, X.; Zhang, W.; Wang, H.; Xu, S.; Fang, Q.; Liu, H.; Yang, W.; Lou, J. Involvement of Dynamin-Related Protein 1 in Free Fatty Acid-Induced INS-1-Derived Cell Apoptosis. PLoS ONE 2012, 7, e49258. [CrossRef] [PubMed]

166. Taddeo, E.P.; Alsabeeh, N.; Baghdasarian, S.; Wikstrom, J.D.; Ritou, E.; Sereda, S.; Erion, K.; Li, J.; Stiles, L.; Abdulla, M.; et al. Mitochondrial proton leak regulated by Cyclophilin D elevates insulin secretion in islets at nonstimulatory glucose levels. Diabetes 2020, 69, 131-145. [CrossRef] [PubMed]

167. Larsson, O.; Deeney, J.T.; Bränström, R.; Berggren, P.O.; Corkey, B.E. Activation of the ATP-sensitive K+ channel by long chain acyl-CoA: A role in modulation of pancreatic $\beta$-cell glucose sensitivity. J. Biol. Chem. 1996, 271, 10623-10626. [CrossRef] [PubMed]

168. Bränström, R.; Aspinwall, C.A.; Välimäki, S.; Östensson, C.G.; Tibell, A.; Eckhard, M.; Brandhorst, H.; Corkey, B.E.; Berggren, P.O.; Larsson, O. Long-Chain CoA esters activate human pancreatic beta-cell KATP channels: Potential role in Type 2 diabetes. Diabetologia 2004, 47, 277-283. [CrossRef]

169. Antollini, S.S.; Barrantes, F.J. Fatty Acid Regulation of Voltage- and Ligand-Gated Ion Channel Function. Front. Physiol. 2016, 7, 573. [CrossRef]

170. Remizov, O.; Jakubov, R.; Düfer, M.; Drews, P.K.; Drews, G.; Waring, M.; Brabant, G.; Wienbergen, A.; Rustenbeck, I.; Schöfl, C. Palmitate-induced Ca2+-signaling in pancreatic beta-cells. Mol. Cell. Endocrinol. 2003, 212, 1-9. [CrossRef] [PubMed] 
171. Komatsu, M.; Yajima, H.; Yamada, S.; Kaneko, T.; Sato, Y.; Yamauchi, K.; Hashizume, K.; Aizawa, T. Augmentation of Ca2+stimulated insulin release by glucose and long- chain fatty acids in rat pancreatic islets: Free fatty acids mimic ATP- sensitive K+ channel-independent insulinotropic action of glucose. Diabetes 1999, 48, 1543-1549. [CrossRef]

172. El-Assaad, W.; Buteau, J.; Peyot, M.L.; Nolan, C.; Roduit, R.; Hardy, S.; Joly, E.; Dbaibo, G.; Rosenberg, L.; Prentki, M. Saturated fatty acids synergize with elevated glucose to cause pancreatic $\beta$-cell death. Endocrinology 2003, 144, 4154-4163. [CrossRef]

173. Maestre, I.; Jordán, J.; Calvo, S.; Reig, J.A.; Ceña, V.; Soria, B.; Prentki, M.; Roche, E. Mitochondrial dysfunction is involved in apoptosis induced by serum withdrawal and fatty acids in the $\beta$-cell line INS-1. Endocrinology 2003, 144, 335-345. [CrossRef] [PubMed]

174. MATHIAS, S.; PEÑA, L.A.; KOLESNICK, R.N. Signal transduction of stress via ceramide. Biochem. J. 1998, 335, 465-480. [CrossRef]

175. Maedler, K.; Spinas, G.A.; Dyntar, D.; Moritz, W.; Kaiser, N.; Donath, M.Y. Distinct effects of saturated and monounsaturated fatty acids on $\beta$-cell turnover and function. Diabetes 2001, 50, 69-76. [CrossRef] [PubMed]

176. Sokolowska, E.; Blachnio-Zabielska, A. The Role of Ceramides in Insulin Resistance. Front. Endocrinol. 2019, 10, 577. [CrossRef]

177. Itami, N.; Shirasuna, K.; Kuwayama, T.; Iwata, H. Palmitic acid induces ceramide accumulation, mitochondrial protein hyperacetylation, and mitochondrial dysfunction in porcine oocytes. Biol. Reprod. 2018, 98, 644-653. [CrossRef] [PubMed]

178. Syed, I.; Szulc, Z.M.; Ogretmen, B.; Kowluru, A. L-threo-C 6 -pyridinium-ceramide bromide, a novel cationic ceramide, induces NADPH oxidase activation, mitochondrial dysfunction and loss in cell viability in INS 832/13 $\beta$-cells. Cell. Physiol. Biochem. 2012, 30, 1051-1058. [CrossRef] [PubMed]

179. Grishko, V.; Rachek, L.; Musiyenko, S.; LeDoux, S.P.; Wilson, G.L. Involvement of mtDNA damage in free fatty acid-induced apoptosis. Free Radic. Biol. Med. 2005, 38, 755-762. [CrossRef] [PubMed]

180. Veluthakal, R.; Arora, D.K.; Goalstone, M.L.; Kowluru, R.A.; Kowluru, A. Metabolic Stress Induces Caspase-3 Mediated Degradation and Inactivation of Farnesyl and Geranylgeranyl Transferase Activities in Pancreatic $\beta$-Cells. Cell. Physiol. Biochem. 2016, 39, 2110-2120. [CrossRef] [PubMed]

181. Yuan, H.; Zhang, X.; Huang, X.; Lu, Y.; Tang, W.; Man, Y.; Wang, S.; Xi, J.; Li, J. NADPH oxidase 2-derived reactive oxygen species mediate FFAs-Induced dysfunction and apoptosis of b- Cells via JNK, p38 MAPK and p53 pathways. PLoS ONE 2010, 5, e15726. [CrossRef] [PubMed]

182. Barlow, J.; Affourtit, C. Novel insights into pancreatic $\beta$-cell glucolipotoxicity from real-time functional analysis of mitochondrial energy metabolism in INS-1E insulinoma cells. Biochem. J. 2013, 456, 417-426. [CrossRef]

183. Saksida, T.; Stosic-Grujicic, S.; Timotijevic, G.; Sandler, S.; Stojanovic, I. Macrophage migration inhibitory factor deficiency protects pancreatic islets from palmitic acid-induced apoptosis. Immunol. Cell Biol. 2012, 90, 688-698. [CrossRef] [PubMed]

184. Zhu, Y.; Ren, C.; Zhang, M.; Zhong, Y. Perilipin 5 Reduces Oxidative Damage Associated With Lipotoxicity by Activating the PI3K/ERK-Mediated Nrf2-ARE Signaling Pathway in INS-1 Pancreatic $\beta$-Cells. Front. Endocrinol. 2020, 11, 166. [CrossRef] [PubMed]

185. Maedler, K.; Størling, J.; Sturis, J.; Zuellig, R.A.; Spinas, G.A.; Arkhammar, P.O.G.; Mandrup-Poulsen, T.; Donath, M.Y. Glucoseand interleukin- $\beta$-induced $\beta$-cell apoptosis requires Ca2+ influx and extracellular signal-regulated kinase (ERK) $1 / 2$ activation and is prevented by a sulfonylurea receptor 1 /inwardly rectifying $\mathrm{K}+$ channel 6.2 (SUR/Kir6.2) selective potassium channel opener in human islet. Diabetes 2004, 53, 1706-1713. [CrossRef] [PubMed]

186. Song, Z.; Wang, W.; Li, N.; Yan, S.; Rong, K.; Lan, T.; Xia, P. Sphingosine kinase 2 promotes lipotoxicity in pancreatic $\beta$-cells and the progression of diabetes. FASEB J. 2019, 33, 3636-3646. [CrossRef]

187. Tomita, T. Apoptosis in pancreatic $\beta$-islet cells in Type 2 diabetes. Bosn. J. basic Med. Sci. 2016, 16, 162-179. [CrossRef]

188. Koshkin, V.; Dai, F.F.; Robson-Doucette, C.A.; Chan, C.B.; Wheeler, M.B. Limited mitochondrial permeabilization is an early manifestation of palmitate-induced lipotoxicity in pancreatic $\beta$-cells. J. Biol. Chem. 2008, 283, 7936-7948. [CrossRef] [PubMed]

189. Velasquez, C.; Vasquez, J.S.; Balcazar, N. In vitro effect of fatty acids identified in the plasma of obese adolescents on the function of pancreatic $\beta$-cells. Diabetes Metab. J. 2017, 41, 303-315. [CrossRef] [PubMed]

190. Prause, M.; Christensen, D.P.; Billestrup, N.; Mandrup-Poulsen, T. JNK1 protects against glucolipotoxicity-mediated beta-cell apoptosis. PLoS ONE 2014, 9, e87067. [CrossRef]

191. Song, H.; Wohltmann, M.; Tan, M.; Ladenson, J.H.; Turk, J. Group VIA phospholipase A2 mitigates palmitate-induced $\beta$-cell mitochondrial injury and apoptosis. J. Biol. Chem. 2014, 289, 14194-14210. [CrossRef] [PubMed]

192. Green, C.D.; Jump, D.B.; Olson, L.K. Elevated insulin secretion from liver X receptor-activated pancreatic $\beta$-cells involves increased de novo lipid synthesis and triacylglyceride turnover. Endocrinology 2009, 150, 2637-2645. [CrossRef] [PubMed]

193. Oropeza, D.; Jouvet, N.; Bouyakdan, K.; Perron, G.; Ringuette, L.J.; Philipson, L.H.; Kiss, R.S.; Poitout, V.; Alquier, T.; Estall, J.L. PGC-1 coactivators in $\beta$-cells regulate lipid metabolism and are essential for insulin secretion coupled to fatty acids. Mol. Metab. 2015, 4, 811-822. [CrossRef]

194. Li, Z.; Liu, C.; Zhou, Z.; Hu, L.; Deng, L.; Ren, Q.; Qian, H. A novel FFA1 agonist, CPU025, improves glucose-lipid metabolism and alleviates fatty liver in obese-diabetic (ob/ob) mice. Pharmacol. Res. 2020, 153, 104679. [CrossRef] [PubMed]

195. Cho, Y.S.; Kim, C.H.; Kim, K.Y.; Cheon, H.G. Protective effects of arachidonic acid against palmitic acid-mediated lipotoxicity in HIT-T15 cells. Mol. Cell. Biochem. 2012, 364, 19-28. [CrossRef]

196. Schaffer, J.E. Lipotoxicity: When tissues overeat. Curr. Opin. Lipidol. 2003, 14, 281-287. [CrossRef] [PubMed] 
197. Nakajima, S.; Gotoh, M.; Fukasawa, K.; Murakami-Murofushi, K.; Kunugi, H. Oleic acid is a potent inducer for lipid droplet accumulation through its esterification to glycerol by diacylglycerol acyltransferase in primary cortical astrocytes. Brain Res. 2019, 1725, 146484. [CrossRef]

198. Plötz, T.; Hartmann, M.; Lenzen, S.; Elsner, M. The role of lipid droplet formation in the protection of unsaturated fatty acids against palmitic acid induced lipotoxicity to rat insulin-producing cells. Nutr. Metab. 2016, 13, 16. [CrossRef]

199. Tuo, Y.; Wang, D.; Li, S.; Chen, C. Long-term exposure of INS-1 rat insulinoma cells to linoleic acid and glucose in vitro affects cell viability and function through mitochondrial-mediated pathways. Endocrine 2011, 39, 128-138. [CrossRef] [PubMed]

200. Ježek, P.; Jabůrek, M.; Holendová, B.; Plecitá-Hlavatá, L. Fatty Acid-Stimulated Insulin Secretion vs. Lipotoxicity. Molecules 2018, 23, 1483. [CrossRef] [PubMed]

201. Lee, S.; Lee, J.-S. Cellular senescence: A promising strategy for cancer therapy. BMB Rep. 2019, 52, 35-41. [CrossRef]

202. Sone, H.; Kagawa, Y. Pancreatic beta cell senescence contributes to the pathogenesis of type 2 diabetes in high-fat diet-induced diabetic mice. Diabetologia 2005, 48, 58-67. [CrossRef] [PubMed]

203. Deshpande, S.S.; Qi, B.; Park, Y.C.; Irani, K. Constitutive activation of rac1 results in mitochondrial oxidative stress and induces premature endothelial cell senescence. Arterioscler. Thromb. Vasc. Biol. 2003, 23, e1-e6. [CrossRef] [PubMed]

204. Hoa Nguyen, K.; Yao, X.H.; Erickson, A.G.; Mishra, S.; Grégoire Nyomba, B.L. Glucose intolerance in aging male igfbp-3 transgenic mice: Differential effects of human igfbp-3 and its mutant igfbp-3 devoid of igf binding ability. Endocrinology 2015, 156, 462-474. [CrossRef]

205. Civelek, M.; Flory, S.; Meloh, H.; Fitzenberger, E.; Wenzel, U. The polyphenol quercetin protects from glucotoxicity depending on the aggresome in Caenorhabditis elegans. Eur. J. Nutr. 2020, 59, 485-491. [CrossRef] [PubMed]

206. Moens, C.; Bensellam, M.; Himpe, E.; Muller, C.J.F.; Jonas, J.; Bouwens, L. Aspalathin Protects Insulin-Producing $\beta$ Cells against Glucotoxicity and Oxidative Stress-Induced Cell Death. Mol. Nutr. Food Res. 2020, 64, e1901009. [CrossRef]

207. Ben Salem, M.; Ben Abdallah Kolsi, R.; Dhouibi, R.; Ksouda, K.; Charfi, S.; Yaich, M.; Hammami, S.; Sahnoun, Z.; Zeghal, K.M.; Jamoussi, K.; et al. Protective effects of Cynara scolymus leaves extract on metabolic disorders and oxidative stress in alloxandiabetic rats. BMC Complement. Altern. Med. 2017, 17, 328. [CrossRef]

208. Galli, A.; Marciani, P.; Marku, A.; Ghislanzoni, S.; Bertuzzi, F.; Rossi, R.; Di Giancamillo, A.; Castagna, M.; Perego, C. Verbascoside Protects Pancreatic $\beta$-Cells against ER-Stress. Biomedicines 2020, 8, 582. [CrossRef]

209. Zakłos-Szyda, M.; Majewska, I.; Redzynia, M.; Koziołkiewicz, M. Antidiabetic Effect of Polyphenolic Extracts from Selected Edible Plants as $\alpha$-Amylase, $\alpha$-Glucosidase and PTP1B Inhibitors, and $\beta$ Pancreatic Cells Cytoprotective Agents-A Comparative Study. Curr. Top. Med. Chem. 2015, 15, 2431-2444. [CrossRef] [PubMed]

210. Mollica, A.; Stefanucci, A.; Zengin, G.; Locatelli, M.; Macedonio, G.; Orlando, G.; Ferrante, C.; Menghini, L.; Recinella, L.; Leone, S.; et al. Polyphenolic composition, enzyme inhibitory effects ex-vivo and in-vivo studies on two Brassicaceae of northcentral Italy. Biomed. Pharmacother. 2018, 107, 129-138. [CrossRef]

211. Ben Khedher, M.R.; Hafsa, J.; Haddad, M.; Hammami, M. Inhibition of Protein Glycation by Combined Antioxidant and Antiglycation Constituents from a Phenolic Fraction of Sage (Salvia officinalis L.). Plant Foods Hum. Nutr. 2020, 75, 505-511. [CrossRef] [PubMed]

212. Liu, C.G.; Ma, Y.P.; Zhang, X.J. Effects of mulberry leaf polysaccharide on oxidative stress in pancreatic $\beta$-cells of type 2 diabetic rats. Eur. Rev. Med. Pharmacol. Sci. 2017, 21, 2482-2488.

213. Gharib, E.; Kouhsari, S.M.; Izad, M. Punica granatum L. Fruit aqueous extract suppresses reactive oxygen species-mediated p53/p65/miR-145 expressions followed by Elevated Levels of irs-1 in alloxan-diabetic rats. Cell J. 2018, 19, 520-527. [CrossRef]

214. Hao, F.; Kang, J.; Cao, Y.; Fan, S.; Yang, H.; An, Y.; Pan, Y.; Tie, L.; Li, X. Curcumin attenuates palmitate-induced apoptosis in MIN6 pancreatic $\beta$-cells through PI3K/Akt/FoxO1 and mitochondrial survival pathways. Apoptosis 2015, 20, 1420-1432. [CrossRef]

215. Zhang, Y.; Zhen, W.; Maechler, P.; Liu, D. Small molecule kaempferol modulates PDX-1 protein expression and subsequently promotes pancreatic $\beta$-cell survival and function via CREB. J. Nutr. Biochem. 2013, 24, 638-646. [CrossRef] [PubMed]

216. Huang, C.N.; Wang, C.J.; Lee, Y.J.; Peng, C.H. Active subfractions of Abelmoschus esculentus substantially prevent free fatty acid-induced $B$ cell apoptosis via inhibiting dipeptidyl peptidase-4. PLoS ONE 2017, 12, e0180285. [CrossRef]

217. McCarty, M.F. A chlorogenic acid-induced increase in GLP-1 production may mediate the impact of heavy coffee consumption on diabetes risk. Med. Hypotheses 2005, 64, 848-853. [CrossRef] [PubMed]

218. Paolisso, G.; Giugliano, D.; D’Amore, A.; Varricchio, M.; Galzerano, D.; D’Onofrio, F.; Balbi, V. Daily vitamin E supplements improve metabolic control but not insulin secretion in elderly type II diabetic patients. Diabetes Care 1993, 16, $1433-1437$. [CrossRef] [PubMed]

219. Kwak, H.J.; Yang, D.; Hwang, Y.; Jun, H.S.; Cheon, H.G. Baicalein protects rat insulinoma INS-1 cells from palmitate-induced lipotoxicity by inducing HO-1. PLoS ONE 2017, 12, e0176432. [CrossRef] 